\title{
Subsidiary divestiture and acquisition in a financial crisis: Operational focus, financial constraints, and ownership
}

\author{
Yue Maggie Zhou ${ }^{\mathrm{a}, *}$, Xiaoyang $\mathrm{Li}^{\mathrm{b}}$, Jan Svejnar ${ }^{\mathrm{b}}$ \\ ${ }^{a}$ Robert Smith School of Business, University of Maryland, United States \\ b Stephen M. Ross School of Business, University of Michigan, United States
}

\section{A R T I C L E I N F O}

Available online 25 September 2010

\section{JEL classification:}

G34

Keywords:

Divestiture

Corporate restructuring

Financial constraints

Financial crisis

Multinational corporations

\begin{abstract}
A B S T R A C T
We exploit parent- and subsidiary-level data for publicly listed firms in Thailand before, during, and after the 1997 Asian Financial Crisis to investigate the extent to which firms with different types of ownership restructure their business portfolios, in terms of divestitures and acquisitions. We compare restructuring choices made by firms mostly owned by (a) domestic individuals with block shares (family firms), (b) domestic firms and/or institutions (DI firms), and (c) foreign investors (foreign firms). We show that following the crisis (1) foreign firms' restructuring behavior is the least affected; (2) domestic firms owned by families and domestic institutions (DI) behave similarly to one another; (3) domestic firms do not increase divestiture in their peripheral segments to improve operational focus or to obtain cash in a credit crunch; they actually reduce divestiture in core segments; and (4) domestic firms also significantly reduce the acquisition of new subsidiaries. Our results challenge traditional explanations for divestiture such as corporate governance, operational refocus, and financial constraints. They indicate that in the great uncertainty of a crisis, domestic firms are able to hold onto their core assets to avoid fire-sale. In essence, they act more conservatively in churning their business portfolios.
\end{abstract}

\section{Introduction}

Business portfolio restructuring - firms adding and/or divesting assets, such as subsidiaries - is a common corporate phenomenon and a topic of broad interest to both strategy and finance scholars. Prior research suggests that firms restructure their portfolios for two main objectives: to improve operational efficiency or to raise external funds. In particular, the literature proposes two circumstances under which firms divest their assets: when they have over-diversified in the past and need to refocus their business to improve efficiency (see Berger and Ofek, 1995; and Comment and Jarrell, 1995), or when they are financially constrained and need to raise external funds (see Lang et al., 1995). Whereas restructuring to improve operational efficiency may be an optimal strategy in the long run, restructuring purely for financing purposes may not, especially if the financial constraints are temporary. In the case of divestiture, to avoid bankruptcy, firms may have to divest assets that are valuable in the long run had it been able to survive the temporary financial constraints. Unfortunately, it is often difficult to discern the two scenarios based on empirical data. Firms that have over-diversified are also likely to have overstretched their financial capital and have high leverage ratios. When they divest, it is hard to conclude whether they do so to refocus or to alleviate financial constraints. Similarly, firms

* Corresponding author. Robert Smith School of Business, University of Maryland, 3345 Van Munching Hall, College Park, MD 20742, United States. Tel.: +1 301 405 5256; fax: +1 3013141023 .

E-mail address: ymzhou@rhsmith.umd.edu (Y.M. Zhou). 
that are financially constrained are also likely to show lower profitability due to their suboptimal capital (as opposed to business) structure. When they divest, it is hard to conclude whether they do so to improve operational efficiency or to raise funds. As a simplification, the literature often associates divestiture of assets in firms' peripheral segments, especially by firms with poor corporate governance, with efficiency-improving refocusing.

In this study we exploit an exogenous shock - the Asian Financial Crisis - to examine the restructuring choices of firms in Thailand. We compare the restructuring behavior of publicly listed firms in Thailand that are mostly owned by individuals with block shares (family firms) to that of firms mostly owned by domestic firms and institutions (DI firms) and those owned by foreign investors (foreign firms). We also contrast the restructuring behavior of these firms over three time periods: pre-crisis (19941996), crisis (1997-1999), and post-crisis (2000-2002). We choose the crisis and Thailand for three reasons. First, the unprecedented financial crisis in the late 1990s made corporate restructuring an important strategic decision. The crisis dramatically changed the outlook of many business opportunities, which makes operational efficiency objective that is traditionally associated with divestiture even more salient. Second, the local financial markets in Thailand were under-developed, and domestic firms may have faced tighter financial constraints than foreign firms that could finance themselves through their global internal capital markets (see Foley et al., 2008). This unique setting allows us to study the differential impact of the financial crisis on firms with potentially different financial constraints. Third, the context enables us to minimize the issue of endogeneity of ownership and business structures. Thailand was the first country hit by the crisis, and the society at large and firms in particular were taken by surprise. Such unexpected onset of a major crisis provides a major exogenous shock that we can exploit to compare the nature of the responses from the three types of firms.

We first evaluate the refocusing hypothesis to understand different firms' motives for divestiture. Refocusing entails divesting peripheral businesses that the firm has diversified into in the past (Berger and Ofek, 1999). Diversification is often associated with a "discount" in the market valuation of the firm. The "diversification discount" arises partly because over-diversification is commonly associated with agency problems in poorly governed firms. These firms are more likely to over-invest in businesses with marginal revenue below marginal investment cost (Berger and Ofek, 1995). They are also more likely to cross-subsidize, allocating resources from business lines of greater profit potential to those of less potential, hurting the overall performance (Daley et al., 1997). Finally, they are more likely to mingle different business lines together, making them difficult to evaluate for external investors (Krishnaswami and Subramaniam, 1999). Therefore divestitures that increase corporate focus are often associated with a perceived alleviation of agency problem and therefore positive market response (see Berger and Ofek, 1999; Burch and Nanda, 2003; Daley et al., 1997; and Dittmar and Shivdasani, 2003).

To the extent that firms with different ownership vary in agency problems, they may also vary in diversification and subsequent divestment. As pointed out by Claessens et al. (2002), there are two types of agency problems. The first is a manager vs. shareholder agency problem caused by the conflict of interests between managers and shareholders (Jensen and Meckling, 1976). The second is a controlling vs. minority shareholder agency problem as large shareholder can use their control to maximize their private benefit at the cost of minority shareholders (see Shleifer and Vishny, 1986). As suggested by Villalonga and Amit, 2006, family firms are firms with concentrated ownership by individuals who have greater incentive than minority shareholders to monitor managers and who often assume management positions themselves; they therefore have less of a manager vs. shareholder agency problem compared to other firms. On the other hand, family firms have a more severe controlling vs. minority shareholder agency problem and can extract private benefits more easily than other firms. The net effect of family ownership on firm behavior and performance may go either way and is likely to vary by context. Anderson and Reeb (2003a), for example, document that family firms perform better than nonfamily firms. However, the performance effect varies by CEO status. CEOs who are family members (founders or founder descendants) are associated with higher profitability. Villalonga and Amit (2006) find that descendent CEOs destroy shareholder values. In the context of some East Asian countries, several authors suggest that the worsened controlling vs. minority shareholder agency problem associated with family ownership is likely to overshadow the reduction in managerial incentive problem. Claessens et al. (2000) find that a sharp divergence between ownership and control rights exists in East Asian countries, due to strong presence of family firms. Bertrand et al. (2008) provide additional supporting evidence particularly for Thailand.

If the controlling vs. minority shareholders agency problems are indeed more severe in family firms than in other firms, they are more likely to over-diversify their firms to reduce the risk of their concentrated personal wealth (see Shleifer and Vishny, 1997). The role of the crisis is ambiguous. On the one hand, it may act as a disciplinary mechanism. The risk of bankruptcy may provide strong incentive for managerial effort, because bankruptcy can lead to loss of private benefits including the future opportunities to "tunnel" resources out of the firm at the cost of minority shareholders. As firms' performance deteriorates because of the crisis, minority shareholders may also take a closer look at the firms' operations and governance to make sure the firm will not default or go bankrupt. Berger and Ofek (1999) and Johnson et al. (1993) point out that potential strengthening of corporate governance provoked by poor performance is likely to force entrenched insiders to restructure their portfolio and focus on their core business. As external financing becomes less available to all firms during the crisis, and firms' performance deterioration increases the likelihood of bankruptcy, large shareholders in family firms may choose to "tunnel" less resources out of their firms to keep the firms afloat. Under these circumstances, one would expect family firms to start behaving more like well governed firms and refocus more during the crisis than before the crisis.

Following prior literature on refocusing, we define refocusing as divestiture in a firm's peripheral segment, whereby the divested subsidiary operates outside of the parent's main two-digit SIC codes. Berger and Ofek (1999) find that firms are more likely to refocus (divest) if they have diversified into unrelated business lines (with different two-digit SIC codes). Daley et al. (1997) find that cross-industry spin-offs, where the parent and the spun-off subsidiary belong to different two-digit SIC codes, 
create more value than within-industry spin-offs. John and Ofek (1995) and Desai and Jain (1999) in turn find that for firms that divest or spin off subsidiaries in different two or four-digit SIC industry, the parents experience subsequent improvements in operating and stock-market performance. The large body of literature on diversification has also used firms' entrance into industries with different two-digit SIC codes as their main operations to define unrelated diversification. Given that a main reason for refocusing is to reduce the "diversification discount" caused by unrelated diversification, it makes sense that similar measures of unrelated diversification and refocusing are used. Therefore, if the crisis has acted as a disciplinary mechanism, one would expect family firms to divest more and acquire fewer peripheral assets during the crisis than before the crisis.

On the other hand, the crisis can also aggravate the controlling vs. minority shareholder agency problems within family firms. As argued by various authors such as Baek et al. (2004) and Lemmon and Lins (2003), the crisis may make it easier for the controlling shareholders to expropriate minority shareholders since the crisis negatively impacts firms' investment opportunities, and the marginal cost to insiders of diverting firm resources away from profitable investment projects. Under these circumstances, one would expect family firms to divest more core assets to support other business ventures in their portfolios/business groups, a phenomenon called "tunneling" as in Johnson et al. (2000). Tunneling is especially prevalent in family firms with pyramidal ownership structures where the wedge between voting and cash flow rights increases with distance from the pyramid apex.

Our empirical findings, however, refute both hypotheses. We find that before the crisis family firms do not differ significantly from DI or foreign firms in their divestiture behavior. During the crisis, compared with DI firms, family firms do not divest more peripheral assets to improve operational focus, nor do they divest more core segments to tunnel resources away from their main business. Our findings suggest that family firms do not behave differently from the DI firms and that operational focus or tunneling may not be the primary objective in domestic firms' divestiture decisions during the crisis.

We next examine the financial constraint hypothesis for divestiture. According to Lang et al. (1995), firms are expected to divest assets to obtain expedient funds when their access to the external capital markets is limited. These authors, as well as Andrade and Kaplan (1998), find that firms with high leverage are more likely to engage in asset sales to avoid or mitigate the possible costs of financial distress. In order to test the financial constraint hypothesis, we focus on comparing the behavior of domestic versus foreign firms before, during and after the crisis. Domestic firms in our sample are more financially constrained than foreign firms throughout the sample period along multiple dimensions. For example, they have higher debt-to-equity ratio, lower interest coverage ratio and lower current ratio. They therefore may be more likely to divest than foreign firms. Moreover, during the local (Thai) crisis they are likely to suffer greater tightening of the financial constraint than do subsidiaries of MNCs and thus resort more to divesting. Yet, we find that while foreign firms do not react much (as expected) during the crisis, domestic firms reduce rather than increase divestiture. This contradicts the financial constraint hypothesis.

In order to provide a more complete picture, we proceed from an analysis of divestitures to investigate the acquisition of new subsidiaries. We find that during the crisis domestic firms reduce not only divestiture but also the acquisition of new subsidiaries. Foreign firms reduce subsidiary acquisition as well, but not as much as the domestic firms; their total restructuring (subsidiary acquisition and divestiture) is the least affected. These findings suggest that divestiture and acquisition, two components of corporate restructuring, are used differently by foreign and domestic firms. Interestingly, our results imply a difference between foreign and domestic firms, rather than between family and other domestic firms, in their restructuring behavior. Both types of domestic firms act more conservatively in churning their businesses under the increased uncertainty of the crisis. This is consistent with them being more risk adverse given their limited geographic diversification and alternative sources of funding.

Despite their financial constraints, firms may be reluctant to sell their valuable assets during a crisis because distress in the markets with too many sellers and a few hesitant buyers depresses asset prices (see Shleifer and Vishny, 1992), a phenomenon that is best known as fire-sale and has regained scholar interest during the current global financial crisis (see Diamond and Rajan, 2009; and Sidel et al., 2008). The problem is especially severe in countries with a weak regulatory framework for bankruptcy such as Chapter 11 protection (see Easterbrook (1990), as in the case of Thailand (see Foley, 2001). Our finding that firms reduce subsidiary acquisition rather than increasing divestiture to relax financial constraints, and that after controlling for subsidiary addition, firms divest fewer subsidiaries in their core segments following crisis than pre-crisis but no fewer subsidiaries in their peripheral segments is consistent with the conjecture that local firms may be able to avoid fire-sale of their core assets that will be useful once the crisis is over.

Besides the broad literature on corporate restructuring, our study relates to recent research on fire-sale in financial crisis, especially in emerging markets such as East Asia (see Acharya et al., 2007a,b; Aguiar and Gopinath, 2005; and Krugman, 1998). It has been documented that foreign strategic investors acquired a significantly larger (four to six times) numbers of domestic firms during the Asian crisis than before, mainly to take advantage of cheap assets in crisis-stricken countries (see UNCTAD, 1999). Our study examines domestic firms' defensive reaction to the potential fire-sale of their core assets at a micro-level.

Our paper also sheds light on the different impact of financial crisis on domestic and multinational corporations (MNCs). Our results hold after we control for the existing level of financial constraints at the firm level. This implies that foreign firms may lower their cost of financial distress through their unique organizational form. Foley et al. (2008) find that even though a currency crisis makes exporters in crisis countries more competitive, domestic exporters are not able to benefit from the cheap currency to increase sales and save costs because of financial constraints. In contrast, MNCs in the crisis countries are able to take advantage of the market opportunities through their internal capital markets around the globe. Our finding that domestic firms are much less likely than foreign firms to have a net increase of subsidiaries during the crisis suggests a micro-mechanism for MNCs to improve their market position relative to domestic firms during a financial crisis.

The paper proceeds as follows. The next section describes the empirical setting and the research design. We present our analyses in Section 3. Finally, we discuss the limitations and conclude in Section 4. 


\section{Thailand and Asian Financial Crisis}

After decades of continuous growth well into the 1990s, Thailand was among the fastest-growing Newly Industrialized Countries and acclaimed as one of the "economic miracles" by international capital markets and organizations like the World Bank (1993). The Thai economy, however, has the same kind of structural problems that are typical of developing economies. One problem was its currency policy. Like many Asian countries, Thailand liberalized its financial and capital markets in the early 90s but kept its currency, the baht, pegged to the U.S. dollar. The liberalized capital markets (with high domestic interest rates) and a fixed currency regime attracted a flood of speculative short-term capital (see Stiglitz, 2000), or "hot money," which had become a key form of bank lending. As the U.S. dollar appreciated, exports from these Asian countries became expensive, which was followed by decreased sales and increased trade deficit. In early 1997, expecting that governments in these countries would soon devalue their currencies to keep the competitiveness of their exports, international currency speculators started to short-sell these countries' currencies. They started with the Thai baht. The government of Thailand kept buying baht with dollars to defend its currency until the dollar reserve was depleted. On July 2, 1997, the government gave up the fixed rate regime. The Thai baht plummeted against the dollar by more than $20 \%$ on the news. The global financial markets panicked. The crisis quickly spread to Malaysia, Indonesia, and Korea before the end of the year, and to Russia, Japan, and Brazil the following year. To instill confidence, the country undertook several drastic measures, including raising domestic interest rates to historical highs and closing 56 insolvent finance companies, as part of the economic restructuring plan. The credit crunch led to a deep recession. For example, the cumulative net loss of the firms listed on the Stock Exchange of Thailand amounted to one-third of the country's GDP (Vongvipanond and Wichitaksorn, 2004). The country started to recover after 1999 (Fig. 1), though about 40\% of its loans were still not performing in 2000 (see Stiglitz, 2000).

Family business has a long history in Thailand, as described in Hewison (1989) and Pasuk and Baker (2002). A majority of the Thai business groups are owned by Chinese families that immigrated to Thailand shortly after the Opium War of 1840-1842. Most of them were established in the late nineteenth to early twentieth century. They have expanded together with the Thai domestic economy since the 1970s with the opening of the Security Exchange of Thailand, and have made significant contribution to Thailand's domestic economic output (see Hewison, 2003). Like all domestic businesses in Thailand, family firms also suffered a great deal during the crisis, which forced several companies into bankruptcy and the transfer of ownership of several prominent family firms into foreign hands (see Pasuk and Baker, 2002).

The economic and currency crisis is particularly damaging to domestic firms in Thailand. According to authors' tabulations using Mergers and Acquisition data in SDC Platinum, the number of acquisition deals in Thailand more than doubled from 136 in 1997 to 339 in 1998, and the number of deals involving foreign acquirers more than tripled from 64 in 1997 to 211 in 1998 . These numbers are consistent with studies on fire-sale of domestic firms during the Asian Financial Crisis. The United Nations reports that foreign direct investment into Thailand jumped by more than four-fold to $\$ 7$ billion in 1998 , compared to average flow between 1991 and 1995, mainly due to multinational firms taking advantage of cheap assets in crisis-stricken countries (see Acharya et al., 2007a,b; and UNCTAD, 1999). Aguiar and Gopinath (2005) find that foreign acquisitions increased by $91 \%$ in East Asia between 1996 and 1998, despite the decline in international merger activity; lack of liquidity for domestic firms played a significant role in the increase.

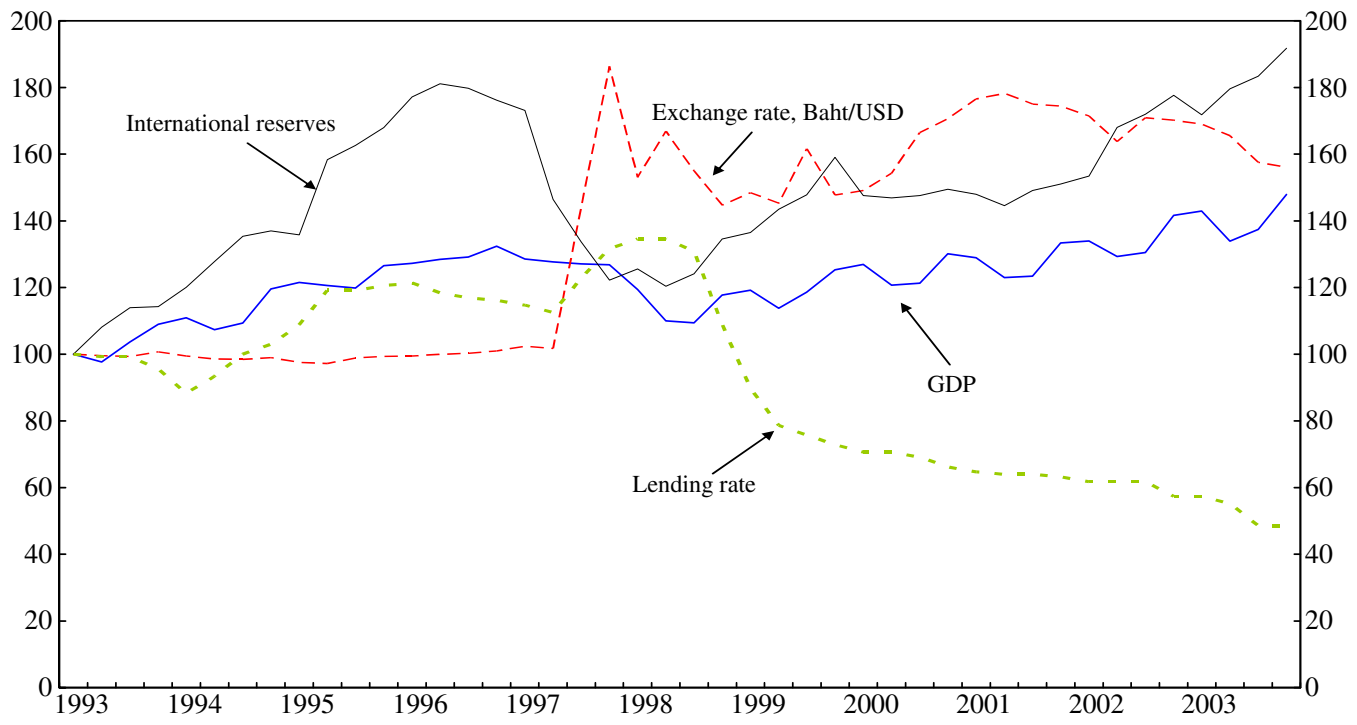

Fig. 1. Macroeconomic indicators for Thailand: 1993-2003. Source: International Monetary Fund. 

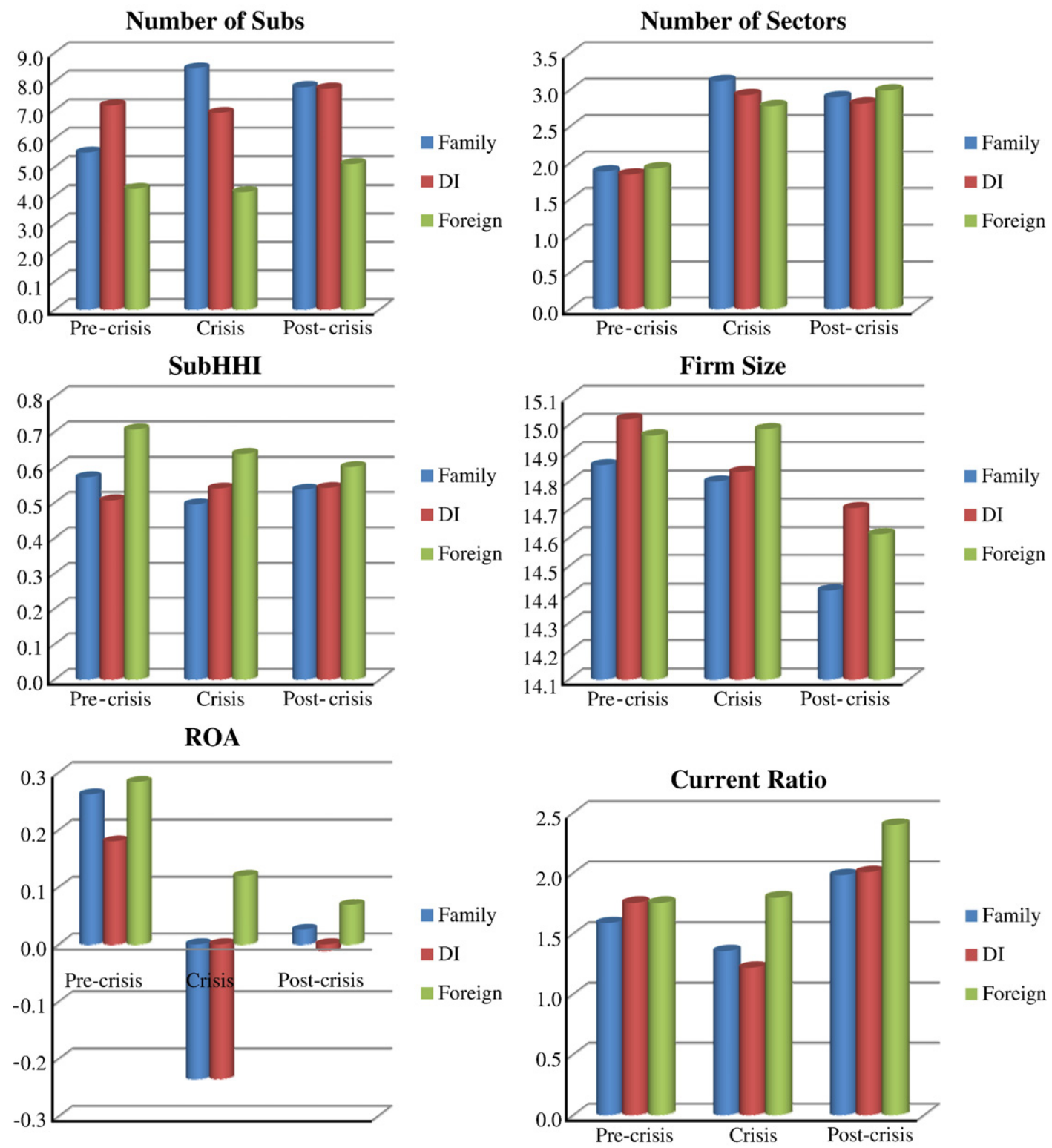

Fig. 2. Diversification, financial constraints, and performance across ownership types and periods.

\section{Empirical analysis}

In this section, we compare and contrast how firms of different ownership types change their subsidiary portfolios following the crisis.

\subsection{Sample and variable description}

We gather information for all companies listed on the Stock Exchange of Thailand (SET) from 1994 to 2003. The firms are in 30 two-digit SIC equivalent sectors. We restrict our sample to firms that have at least one subsidiary at the outset of the crisis: 1997. We also delete firms with incomplete information on assets, earnings and liquidity. We find 214 of them and follow them throughout entire sample period (1994-2003). They made up about 75\% of market capitalization of all firms listed on the SET with at least one subsidiary and $60 \%$ of all firms listed on the SET. We call them "parent companies" or "parents" and obtain their balance sheet information from the SET.

The parent companies are required by the SET to report information on their subsidiaries, including each subsidiary's paid-in capital, sector, and the parent's ownership stake in the subsidiary. We obtain such subsidiary information for the year-ends of 1994, 1997, 2000, and 2003, respectively. The 214 parent companies in our sample have 1145 subsidiaries in 1994,1290 
Table 1a

Number of firms and their subsidiaries (in parentheses) by ownership types and periods.

\begin{tabular}{|c|c|c|c|}
\hline Firm type & 1994 & 1997 & 2000 \\
\hline FAMILY & $101(476)$ & $93(710)$ & $81(575)$ \\
\hline DI & 87 (577) & $80(511)$ & $72(514)$ \\
\hline FOREIGN & $26(92)$ & $18(69)$ & $23(101)$ \\
\hline ALL & $214(1145)$ & $191(1290)$ & $176(1190)$ \\
\hline
\end{tabular}

subsidiaries in 1997, and 1190 in 2000 (Table 1a). We divide our sample period into three three-year periods: pre-crisis period (1994-1996), crisis period (1997-1999), and post-crisis period (2000-2002). For each period we identify divestiture by comparing the list of subsidiaries at the end of the period with the list at the beginning of the period. If a subsidiary exists at the end of 1997 (i.e., the beginning of the crisis period) but not in 2000 (i.e., the last year of the crisis period), then it is considered as being divested during the crisis period. Similarly, if a subsidiary exists at the end of 1994 but not in 1997, then it is divested during the pre-crisis period; if it exists at the end of 2000 but not in 2003, then it is divested during the post-crisis period. Our final sample has 581 parent-period and about 3625 subsidiary-period observations.

Our first set of dependent variables is about subsidiary divestiture. At the subsidiary level, DIVESTITURE is defined as a binary variable that equals 0 by default but changes to 1 in the period when a particular subsidiary is not on the subsidiary list of its former parent at the end of that period. At the parent level, TOTAL DIVESTITURE is the total number of subsidiaries that "disappear" from a parent's subsidiary list at the end of a period compared with the subsidiary list at the beginning of the period. ${ }^{1}$ We also define two supplementary dependent variables at the parent level. CORE DIVESTITURE is the number of subsidiaries a parent divests that are in the same sector as the parent (core segment). PERIPHERAL DIVESTITURE is the number of subsidiaries a parent divests that are in a different sector from its own (peripheral segment). ${ }^{2}$

Our second set of dependent variables is about subsidiary addition. TOTAL EXPANSION is the number of subsidiaries a parent adds in a period. CORE EXPANSION and PERIPHERAL EXPANSION are the number of subsidiaries a parent adds in its core and peripheral segment, respectively. Finally, we subtract the number of divestitures from expansion to obtain the net change in firms' subsidiary portfolios.

The key independent variables are parents' ownership types. We classify parents into three ownership types according to shares owned by their top ten shareholders at the beginning of each period (i.e., at the year-ends of 1994, 1997, and 2000, respectively). On average, the largest group of shareholders own more than $40 \%$ of the shares in parent companies. The tenthlargest shareholder owns about 5\%. Among the ten largest shareholders for each parent, we calculate the sum of shares owned by domestic individuals, domestic institutions, and foreign investors, respectively. We define a parent as a FAMILY firm if among the ten largest shareholders domestic individuals collectively own the most shares, a DI firm if domestic institutions collectively own the most shares, and a FOREIGN firm if foreign investors collectively own the most shares.

To address the issue of pyramidal ownership structure and group affiliation that might conceal family ownership, we define family firms to include not only firms in which individual shareholders own more shares than domestic institutions and foreigners among the ten largest shareholders, but also firms that belong to a prominent business group. The later expansion is intended to capture firms that are under family control beyond ownership and have financial resources outside what is on their firm balance sheets. We manually check our sample firms' business group affiliation by reading the detailed information on the 150 Thai business groups provided by Brooker Group and TARA (1997), which has been used as a source of information by prior studies on family firms in Thailand, e.g., Bertrand et al. (2008).

A typical FAMILY is founded and owned by Thai individuals. For example, the Dusit Thani Public Company Limited is a Bangkokbased hotel and resort company. It is a member of the Dusit Thani Group founded in 1949 by Than Phu Ying Chanut Piyaoui, who is also the CEO and chair of the Company. Its ownership is highly concentrated; the largest five shareholders own more than $80 \%$ of the shares. A quarter of the management team is composed of family members. The Company owns properties in Thailand, as well as properties in Myanmar, the Philippines, Indonesia, the United Arab Emirates, Germany, and the United States. It sold many overseas ventures during the crisis.

DI firms are firms in which domestic firms and institutions own the largest share among the top ten shareholders. For example, President Rice Products was established by a group of Thai industrial firms. It was later listed on SET and mostly owned by domestic companies.

FOREIGN firms include Thai subsidiaries of MNCs, such as the Singer Sewing Machine Company, which is a subsidiary of a U.S. parent, and distributes U.S. Singer sewing machines, refrigerators, and a greater variety of other electrical appliances. Foreign firms also include other Thai firms with significant ownership by foreign investors. For example, Thai Industrial Gases Public Company Limited, a foreign firm in our sample, was established in 1970 but later was partially acquired by German's Linde Group, the world

\footnotetext{
1 To address the concern that subsidiary disappearance might be asset amalgamation, we run a regression of logged value of Plant, Property and Equipment (PPE) on lagged divestiture in the form of $\log (\mathrm{PPE})_{T+1}=\alpha+\beta$ Divestiture ${ }_{T}+X \gamma+\varepsilon$, the point estimate of $\beta$ is -0.06 , with the $P$ value of 0.02 . This indicates that divestitures are associated with real asset departures. Our results also hold when we use value of divestiture. Due to data limitation, we can only use subsidiary's paid-in capital as proxy for values.

${ }^{2}$ In results not reported here, we also use a continuous variable of percentage of subsidiary's paid-in capital as our dependent variables and our results remain qualitatively unchanged.
} 
Table 1b

Ownership structure by firm type (parent level, $N=581$ ).

\begin{tabular}{|c|c|c|c|}
\hline Firm type & Owned by individual & Owned by DI & Owned by foreigners \\
\hline FAMILY & $41 \%$ & $16 \%$ & $8 \%$ \\
\hline DI & $9 \%$ & $49 \%$ & $10 \%$ \\
\hline FOREIGN & $9 \%$ & $20 \%$ & $41 \%$ \\
\hline
\end{tabular}

Table 2a

Summary statistics - firm level $(N=581)$.

\begin{tabular}{|c|c|c|c|c|c|}
\hline Variable name & Definition & Mean & SD & Min & Max \\
\hline TOTAL DIVESTITURE - firm level & Number of subsidiaries divested by a parent firm & 0.961 & 1.954 & 0 & 18 \\
\hline CORE DIVESTITURE - firm level & $\begin{array}{l}\text { Number of subsidiaries divested by a parent firm that are in the } \\
\text { same sector as the parent firm }\end{array}$ & 0.467 & 1.307 & 0 & 14 \\
\hline PERIPHERAL DIVESTITURE - firm level & $\begin{array}{l}\text { Number of subsidiaries divested by a parent firm that are in a } \\
\text { different sector from the parent firm }\end{array}$ & 0.495 & 1.079 & 0 & 8 \\
\hline FAMILY $(1,0)$ & $\begin{array}{l}\text { Among the ten largest shareholders, domestic (Thai) individuals } \\
\text { collectively own the most shares }\end{array}$ & 0.353 & 0.478 & 0 & 1 \\
\hline DI $(1,0)$ & $\begin{array}{l}\text { Among the ten largest shareholders, domestic institutions } \\
\text { collectively own the most shares }\end{array}$ & 0.513 & 0.500 & 0 & 1 \\
\hline FOREIGN $(1,0)$ & $\begin{array}{l}\text { Among the ten largest shareholders, foreign investors collectively } \\
\text { own the most shares }\end{array}$ & 0.133 & 0.340 & 0 & 1 \\
\hline Change in ROA & Earnings before interests and taxes divided by total assets & .012 & 0.101 & -0.400 & 0.530 \\
\hline FirmSIZE & Logarithm of firm total assets & 14.788 & 1.280 & 12.038 & 18.767 \\
\hline Diversification: No. of subs & Number of subsidiaries of the parent & 6.889 & 8.580 & 1 & 73 \\
\hline Diversification: No. of sectors & Number of sectors the parent and its subsidiaries operate in & 2.547 & 1.985 & 1 & 16 \\
\hline Diversification: SubHHI & Herfindahl index of parent's ownership concentration & 0.533 & 0.291 & 0 & 1 \\
\hline Financial constraints: Current ratio & Current assets divided by current liabilities & 1.677 & 1.677 & 0.041 & 10.714 \\
\hline
\end{tabular}

leader in industrial gases business. The Crown Seal Public Company Limited, another foreign firm in our sample, was acquired by Japan Crown Cork. Even though these foreign owners may not own minority shares, they are the largest shareholders.

In our sample, about $47 \%$ of parents are FAMILY firms, $41 \%$ are DI firms, and $12 \%$ are FOREIGN firms over the entire sample period. Table 1a presents the number of parents by ownership type and the average number of subsidiaries they own at the beginning of each period. Table $1 \mathrm{~b}$ summarizes the detailed ownership structure within each type of firms. On average, individuals hold about $41 \%$ of total shares in family firms, $16 \%$ in a typical DI firm and a little bit less than $10 \%$ in foreign firms. Domestic institutional investors hold about 50\% in DI firms, $16 \%$ in family firms and $20 \%$ in foreign firms. Foreign investors own about $40 \%$ in foreign firms and about $10 \%$ each in family and DI firms, respectively.

While Shleifer and Vishny (1986) observe that block shareholders (like family owners in family firms) tend to reduce the risk of their firms, potentially through diversification and avoidance of debt, Anderson and Reeb (2003b) find that in the U.S., family firms are less diversified than nonfamily firms, and that leverage and equity risk are similar for both family and nonfamily firms. We control for a firm's existing level of focus using three variables calculated at the beginning of each period (i.e., at the year-ends of 1994, 1997, and 2000, respectively). No. of Subs is the total number of subsidiaries owned by the parent. No. of Sectors is the number of sectors in which the parent and its subsidiaries operate. SubHHI reflects the level of concentration for the parent's investments across its subsidiaries. It is calculated based on the share of the parent's investments (in terms of paid-in capital) in each of its subsidiaries, using an equivalent of the Hirschman-Herfindahl Index (HHI). A greater SubHHI means the parent's investments across subsidiaries are more concentrated.

We measure parent firm's liquidity constraints using CURRENT RATIO defined as ratio of current asset to current debt. ${ }^{3}$ Performance deterioration is a key antecedent for restructuring (see Johnson, 1996). We measure performance deterioration using changes in ROA (Return on Assets, defined as earnings before interest and taxes divided by total assets) between the beginning and the end of each period. At the parent level we measure FirmSIZE using the logarithm of total assets (the consolidated value for the parent and its subsidiaries). At the subsidiary level, we control for SubSIZE using the logarithm of its paid-in capital. We also control for SubOWN, percentage share of the subsidiary owned by the parent. Unless otherwise stated, we use mean values, i.e., the average over years 1994-1996, years 1997-1999, and years 2000-2002, to construct pre-crisis, crisis and post-crisis explanatory variables, respectively.

In our sample, $54 \%$ of the parent firms divest at least one subsidiary over the sample period. $36 \%$ and $37 \%$ of the parents firms divest at least one subsidiary in their core and peripheral segment, respectively. Tables $2 \mathrm{a}$ and $2 \mathrm{~b}$ provide summary statistics of key variables at the parent and subsidiary level, respectively. According to the tables, a parent firm divests 0.96 subsidiaries over the sample period, including 0.47 in its core segment. In total, 14\% of the subsidiaries are divested. Table 3 presents

\footnotetext{
${ }^{3}$ We thank a referee for this suggestion.
} 
Table 2b

Summary statistics - subsidiary level $(N=3625)$.

\begin{tabular}{|c|c|c|c|c|c|}
\hline Variable name & Definition & Mean & SD & Min & Max \\
\hline DIVESTITURE - sub level $(1,0)$ & A subsidiary is divested in a given period & 0.134 & 0.340 & 0 & 1 \\
\hline CORE DIVESTITURE - sub level $(1,0)$ & A subsidiary in the parent's core business is divested & 0.070 & 0.260 & 0 & 1 \\
\hline PERIPHERAL DIVESTITURE - sub level $(1,0)$ & A subsidiary in the parent's peripheral business is divested & 0.060 & 0.238 & 0 & 1 \\
\hline FAMILY $(1,0)$ & Owned by a FAMILY parent & 0.494 & 0.500 & 0 & 1 \\
\hline DI $(1,0)$ & Owned by a DI parent & 0.439 & 0.497 & 0 & 1 \\
\hline FOREIGN $(1,0)$ & Owned by a FOREIGN parent & 0.066 & 0.249 & 0 & 1 \\
\hline SubSIZE & Log of paid-in capital & 10.403 & 2.529 & 0.086 & 16.302 \\
\hline SubOwn & Shares of the subsidiary owned by its parent firm & 0.680 & 0.305 & 0.01 & 1 \\
\hline
\end{tabular}

correlations among key variables. Except for the number of sectors ad number of subsidiaries, there is no strong pair-wise correlation.

Fig. 2 compares values for key explanatory variables across ownership types and periods. It shows that domestic firms experience rapid expansion during the pre-crisis period, as evidenced in the increase in number of subsidiaries, number of sectors and firm size. Family firms are very comparable in terms of diversification to DI firms. While foreign firms have increased their number of subsidiaries, their investments remain highly focused (higher SubHHI). Crisis greatly reduces liquidity for all three types of firms, as proxied by current ratio. Foreign firms have the highest current ratios indicating that they are the least financially constrained. The ROA graph shows that the financial crisis hit all firms hard. Firms recover a little in the post-crisis period but are still far from their pre-crisis performance level. Foreign firms perform the best throughout the sample period. Family firms perform slightly better than the DI firms in both pre-crisis and post-crisis periods but perform the worst during the crisis.

\subsection{Specification}

At the parent level, we employ a Poisson model to estimate the effect of ownership structure on firm divestiture behavior around the crisis:

$$
\begin{aligned}
N_{j, T}=\alpha & +\beta_{1} \text { FAMILY }_{j, T-1}+\beta_{2} \text { FOREIGN }_{j, T-1}+\beta_{3} \text { FAMILY }_{j, T-1} * \text { CRISIS }+\beta_{4} \text { FOREIGN }_{j, T-1} * \text { CRISIS }+\beta_{5} \text { DI }_{j, T-1} * \text { CRISIS } \\
& +\beta_{6} \text { FAMILY }_{j, T-1} * \text { POSTCRISIS }+\beta_{7} \text { FOREIGN }_{j, T-1} * \text { POSTCRISIS }+\beta_{8} \text { DI }_{j, T-1} * \text { POSTCRISIS }+X_{j, T-1} * \gamma+\varepsilon_{j, T}
\end{aligned}
$$

where $N_{j, T}$ is the total number of subsidiaries divested (added) by firm $j$ in period $T$, both firm-wide and broken down into its core vs. peripheral business. FAMILY, FOREIGN, and DI are ownership dummies. The base effect of DI ownership is excluded as a benchmark and is contained in the constant term. We interact ownership dummies with crisis and post-crisis dummies to see whether the effects of ownership vary across the three periods. This specification allows us not only to compare the same type of firms' restructuring choices across different time periods, but also to contrast different firms' choices during the same period. For example, $\beta_{1}\left(\beta_{2}\right)$ compares the restructuring choices of FAMILY (FOREIGN) firms with those of DI firms in the pre-crisis period; $\beta_{3}\left(\beta_{4}\right)$ captures the change in choices made by FAMILY (FOREIGN) firms from the pre-crisis to the crisis period; $\beta_{6}\left(\beta_{7}\right)$ captures the change in choices made by FAMILY (FOREIGN) firms from the pre-crisis to the post-crisis period. Therefore, $\beta_{1}+\beta_{3}\left(\beta_{2}+\beta_{4}\right)$ measures the restructuring intensity of FAMILY (FOREIGN) firms in the crisis period, relative to the intensity of DI firms pre-crisis. We interact the CRISIS (POSTCRISIS) dummy with three ownership types to test whether firm behavior differs in the crisis (postcrisis). For instance, difference between $\beta_{3}$ and $\beta_{4}\left(\beta_{5}\right)$ captures the difference between FAMILY and FOREIGN (DI) firm during crisis. Since these three ownership type variables add up to an identity vector, we are decomposing the effect of crisis (post-crisis) into three group effects. $X_{j, T-1}$ is a vector of control variables we mentioned earlier in the paper.

Table 3

\begin{tabular}{|c|c|c|c|c|c|c|c|c|c|c|}
\hline & & (1) & (2) & (3) & (4) & (5) & (6) & (7) & (8) & $(9)$ \\
\hline (1) & Family & 1.00 & & & & & & & & \\
\hline (2) & DI & -0.79 & 1.00 & & & & & & & \\
\hline (3) & Foreign & -0.34 & -0.30 & 1.00 & & & & & & \\
\hline (4) & Change in ROA & -0.01 & 0.03 & -0.03 & 1.00 & & & & & \\
\hline (5) & Firm Size & -0.06 & 0.05 & 0.02 & -0.02 & 1.00 & & & & \\
\hline (6) & No. of subs & 0.03 & 0.03 & -0.10 & 0.10 & 0.40 & 1.00 & & & \\
\hline (7) & No. of sectors & 0.02 & -0.02 & -0.01 & 0.12 & 0.32 & 0.76 & 1.00 & & \\
\hline (8) & SubHHI & -0.04 & -0.05 & 0.14 & -0.10 & -0.21 & -0.54 & -0.48 & 1.00 & \\
\hline (9) & Current ratio & -0.03 & -0.01 & 0.07 & 0.01 & -0.03 & 0.02 & -0.06 & -0.01 & 1.00 \\
\hline
\end{tabular}

Pair-wise correlations (firm level, $N=581$ ). 
At the subsidiary level, we use a Logit model to estimate the probability that a particular subsidiary $i$ of firm $j$ is divested in period $T$, controlling for some firm and subsidiary level variables.

$$
\begin{aligned}
& \operatorname{Pr}\left[Y_{i j, T}=1\right]=\alpha+\beta_{1} \text { FAMILY }_{j, T-1}+\beta_{2} \text { FOREIGN }_{j, T-1}+\beta_{3} \text { FAMILY }_{j, T-1} * \text { CRISIS }+\beta_{4} \text { FOREIGN }_{j, T-1} * \text { CRISIS } \\
& +\beta_{5} \text { DI }_{j, T-1} * \text { CRISIS }+\beta_{6} \text { FAMILY }_{j, T-1} * \text { POSTCRISIS }+\beta_{7} \text { FOREIGN }_{j, T-1} * \text { POSTCRISIS } \\
& +\beta_{8} D_{j, T-1} * \text { POSTCRISIS }+X_{i j, T-1} * \gamma+\varepsilon_{i j, T}
\end{aligned}
$$

Our null hypotheses are: (1) If firms divest subsidiaries to provide liquidity, we expect foreign firms, which face the least financial constraints, to be the least likely to engage in divestiture during crisis than domestic firms. We also expect firms are more likely to engage in divestiture during and post crisis; (2) If firms divest subsidiaries to increase operational focus, we expect firms to divest subsidiaries in their peripheral segments; and (3) family firms, which are shown by the literature to have more severe controlling vs. minority shareholder agency problems, can divest either more or less peripheral relative to core assets during the crisis than non-family domestic firms, depending on whether they view the crisis as a disciplinary mechanism, or as an unique opportunity for tunneling as the costs of suboptimal investments decrease with the crisis.

\subsection{Subsidiary divestiture}

Table 4 reports results from firm level divestiture estimation using Eq. (1). ${ }^{4}$ Looking across models, coefficients of the control variables are fairly consistent with findings from prior literature. Bigger firms with more subsidiaries tend to divest more subsidiaries. Firm size is not statistically significant associated with divestiture partly because we also control for other size measures including number of subsidiaries and number of sectors. More diversified firm with less concentrated investment across subsidiaries (lower subHHI) are more likely to divest subsidiaries. Financially constrained firms with lower current ratio also engage in more divestitures. Performance decline also triggers divestiture, supporting the conclusions in John et al. (1992).

We now turn our attention to the ownership variables and their interactions with period dummies (especially columns 3, 6 and 9). In the pre-crisis period, there is no significant difference between family firms and DI firms in either type of divestiture, but foreign firms divest less in their core segments. During the crisis, family firms reduce their divestiture in the core segments and maintain this lower divestiture level after the crisis. DI firms maintain both their core and peripheral divestitures during the crisis and reduce both of them afterwards. Finally, foreign firms increase their peripheral divestitures during the crisis and reduce them back to the pre-crisis level once the crisis is over. Family firms hence behave during the crisis in a way that is consistent with the hypothesis that firms reduce divestiture to avoid fire-sale of their core assets, while the DI firms display the lower divestiture behavior only with a lag. Foreign firms do not alter their divestiture in core segments during and after the crisis, but increase the divestiture of their peripheral assets during the crisis.

Table 5 reports results from subsidiary level regression using Eq. (2). It estimates the probability that a subsidiary is divested by its parent. Results are mostly consistent with those at the parent level, except that the increase in divestitures of peripheral assets by foreign firms during the crisis is not statistically significant. In addition, subsidiaries in which the parent has more ownership stake are less likely to be divested, suggesting that these subsidiaries may be of more intrinsic value to the parent firm. In addition, larger subsidiaries that are within parents' core sector are less likely to be divested whereas larger subsidiaries outside of parent's core sector are more likely to be divested.

\subsection{Subsidiary addition}

We next provide evidence regarding firm's subsidiary addition decisions in Table 6. On average, larger firms and firms with more existing subsidiaries are more likely to add subsidiaries. Family firms are more aggressive in expansion in core assets before the financial crisis. While foreign firms are least aggressive in adding new subsidiaries before the crisis, they also do not cut back subsidiary addition as much as domestics firms do during and after the crisis. In the core segments, foreign firms in fact do not significantly reduce subsidiary addition during and after the crisis, while domestic firms add more subsidiaries after than during the crisis but still fewer than pre-crisis. In the peripheral segments, foreign firms in fact reduce the number of added subsidiaries even after the crisis. Combining this with our previous results on divestitures, we observe that foreign firms steadily enhance their presence in their core segments both during and after the crisis by maintaining low levels of divestiture and not cutting back acquisitions.

To check the net impact of ownership and crisis, we estimate the probability that a firm has a net positive increase in the number of subsidiaries (number of subsidiaries added net of number of subsidiaries divested) using Eq. (2). Results in Table 7 show that both types of domestic firms are more likely than foreign firms to expand in core segments pre-crisis but, unlike foreign firms, they cut back during the crisis, and after the crisis they only achieve levels of net acquisition that are similar rather than greater than those of foreign firms. Interestingly, while foreign firms are least likely to increase the number of subsidiary pre-crisis, they are able to keep business as usual in their core segment during and after the crisis. In the peripheral segments, foreign firms

\footnotetext{
${ }^{4}$ Our univariate analyses are generally consistent with our multivariate regression results reported here. We do not report the univariate analyses in the paper to conserve space.
} 
Table 4

Poisson estimation of subsidiary divestiture: firm-level evidence.

\begin{tabular}{|c|c|c|c|c|c|c|c|c|c|}
\hline & \multicolumn{3}{|c|}{ Total divestiture } & \multicolumn{3}{|c|}{ Core divestiture } & \multicolumn{3}{|c|}{ Peripheral divestiture } \\
\hline & $(1)$ & $(2)$ & (3) & (4) & (5) & $(6)$ & $(7)$ & $(8)$ & (9) \\
\hline Firm Size & $\begin{array}{l}0.009 \\
(0.19)\end{array}$ & $\begin{array}{l}-0.048 \\
(1.01)\end{array}$ & $\begin{array}{l}-0.041 \\
(0.86)\end{array}$ & $\begin{array}{l}0.023 \\
(0.36)\end{array}$ & $\begin{array}{l}-0.070 \\
(1.04)\end{array}$ & $\begin{array}{l}-0.059 \\
(0.89)\end{array}$ & $\begin{array}{l}0.028 \\
(0.41)\end{array}$ & $\begin{array}{l}0.001 \\
(0.02)\end{array}$ & $\begin{array}{l}0.003 \\
(0.04)\end{array}$ \\
\hline Change in ROA & $\begin{array}{l}-0.942 \\
(2.35)^{* *}\end{array}$ & $\begin{array}{l}-0.798 \\
(1.99)^{* *}\end{array}$ & $\begin{array}{l}-0.778 \\
(1.96)^{* *}\end{array}$ & $\begin{array}{l}-2.455 \\
(4.22)^{* * *}\end{array}$ & $\begin{array}{l}-2.123 \\
(3.64)^{* * *}\end{array}$ & $\begin{array}{l}-2.123 \\
(3.61)^{* * *}\end{array}$ & $\begin{array}{l}0.582 \\
(1.01)\end{array}$ & $\begin{array}{l}0.486 \\
(0.86)\end{array}$ & $\begin{array}{l}0.432 \\
(0.77)\end{array}$ \\
\hline Current ratio & $\begin{array}{l}-0.059 \\
(2.08)^{* *}\end{array}$ & $\begin{array}{l}-0.060 \\
(2.03)^{* *}\end{array}$ & $\begin{array}{l}-0.059 \\
(2.03)^{* *}\end{array}$ & $\begin{array}{l}-0.097 \\
(2.44)^{* *}\end{array}$ & $\begin{array}{l}-0.130 \\
(3.04)^{* * *}\end{array}$ & $\begin{array}{l}-0.130 \\
(3.03)^{* * *}\end{array}$ & $\begin{array}{l}-0.032 \\
(0.78)\end{array}$ & $\begin{array}{l}-0.020 \\
(0.48)\end{array}$ & $\begin{array}{l}-0.019 \\
(0.48)\end{array}$ \\
\hline SubHHI & $\begin{array}{l}-1.848 \\
(7.78)^{* * *}\end{array}$ & $\begin{array}{l}-1.779 \\
(7.55)^{* * *}\end{array}$ & $\begin{array}{l}-1.742 \\
(7.34)^{* * *}\end{array}$ & $\begin{array}{l}-2.302 \\
(6.58)^{* * *}\end{array}$ & $\begin{array}{l}-2.227 \\
(6.41)^{* * *}\end{array}$ & $\begin{array}{l}-2.173 \\
(6.22)^{* * *}\end{array}$ & $\begin{array}{l}-1.472 \\
(4.49)^{* * *}\end{array}$ & $\begin{array}{l}-1.454 \\
(4.44)^{* * *}\end{array}$ & $\begin{array}{l}-1.440 \\
(4.35)^{* * *}\end{array}$ \\
\hline No. of subs & $\begin{array}{l}0.028 \\
(4.56)^{* * *}\end{array}$ & $\begin{array}{l}0.025 \\
(4.01)^{* * *}\end{array}$ & $\begin{array}{l}0.025 \\
(3.98)^{* * *}\end{array}$ & $\begin{array}{l}0.044 \\
(5.33)^{\text {*** }}\end{array}$ & $\begin{array}{l}0.040 \\
(4.87)^{* * *}\end{array}$ & $\begin{array}{l}0.042 \\
(4.90)^{* * *}\end{array}$ & $\begin{array}{l}0.007 \\
(0.71)\end{array}$ & $\begin{array}{l}0.008 \\
(0.79)\end{array}$ & $\begin{array}{l}0.008 \\
(0.77)\end{array}$ \\
\hline No. of sectors & $\begin{array}{l}-0.022 \\
(0.85)\end{array}$ & $\begin{array}{l}0.037 \\
(1.31)\end{array}$ & $\begin{array}{l}0.035 \\
(1.20)\end{array}$ & $\begin{array}{l}-0.168 \\
(4.16)^{* * *}\end{array}$ & $\begin{array}{l}-0.062 \\
(1.44)\end{array}$ & $\begin{array}{l}-0.078 \\
(1.75)^{*}\end{array}$ & $\begin{array}{l}0.098 \\
(2.47)^{\text {** }}\end{array}$ & $\begin{array}{l}0.105 \\
(2.40)^{* *}\end{array}$ & $\begin{array}{l}0.108 \\
(2.42)^{\text {** }}\end{array}$ \\
\hline Family & $\begin{array}{l}0.052 \\
(0.51)\end{array}$ & & $\begin{array}{l}0.081 \\
(0.56)\end{array}$ & $\begin{array}{l}0.033 \\
(0.23)\end{array}$ & & $\begin{array}{l}0.073 \\
(0.40)\end{array}$ & $\begin{array}{l}0.097 \\
(0.65)\end{array}$ & & $\begin{array}{l}0.057 \\
(0.23)\end{array}$ \\
\hline Foreign & $\begin{array}{l}-0.477 \\
(2.19)^{* *}\end{array}$ & & $\begin{array}{l}-0.990 \\
(2.66)^{* * *}\end{array}$ & $\begin{array}{l}-1.206 \\
(2.81)^{* * *}\end{array}$ & & $\begin{array}{l}-1.086 \\
(2.09)^{* *}\end{array}$ & $\begin{array}{l}-0.135 \\
(0.51)\end{array}$ & & $\begin{array}{l}-0.819 \\
(1.53)\end{array}$ \\
\hline Crisis & & $\begin{array}{l}-0.330 \\
(2.77)^{* * *}\end{array}$ & & & $\begin{array}{l}-0.628 \\
(3.66)^{* * *}\end{array}$ & & & $\begin{array}{l}0.101 \\
(0.58)\end{array}$ & \\
\hline Post-crisis & & $\begin{array}{l}-0.726 \\
(5.50)^{* * *}\end{array}$ & & & $\begin{array}{l}-1.184 \\
(6.08)^{* * *}\end{array}$ & & & $\begin{array}{l}-0.215 \\
(1.13)\end{array}$ & \\
\hline Crisis*Family & & & $\begin{array}{l}-0.605 \\
(3.96)^{* * *}\end{array}$ & & & $\begin{array}{l}-0.839 \\
(3.88)^{* * *}\end{array}$ & & & $\begin{array}{l}-0.169 \\
(0.74)\end{array}$ \\
\hline Crisis* Foreign & & & $\begin{array}{l}0.839 \\
(1.78)^{*}\end{array}$ & & & $\begin{array}{l}-0.637 \\
(0.57)\end{array}$ & & & $\begin{array}{l}1.227 \\
(2.04)^{* *}\end{array}$ \\
\hline Crisis*DI & & & $\begin{array}{l}-0.154 \\
(0.92)\end{array}$ & & & $\begin{array}{l}-0.330 \\
(1.39)\end{array}$ & & & $\begin{array}{l}0.171 \\
(0.69)\end{array}$ \\
\hline Post-crisis* Family & & & $\begin{array}{l}-0.548 \\
(3.46)^{* * *}\end{array}$ & & & $\begin{array}{l}-0.891 \\
(3.87)^{* * *}\end{array}$ & & & $\begin{array}{l}-0.043 \\
(0.18)\end{array}$ \\
\hline Post-crisis* Foreign & & & $\begin{array}{l}-0.052 \\
(0.10)\end{array}$ & & & $\begin{array}{l}-1.161 \\
(1.03)\end{array}$ & & & $\begin{array}{l}0.413 \\
(0.63)\end{array}$ \\
\hline Post-crisis*DI & & & $\begin{array}{l}-1.177 \\
(5.23)^{* * *}\end{array}$ & & & $\begin{array}{l}-1.672 \\
(4.88)^{* * *}\end{array}$ & & & $\begin{array}{l}-0.716 \\
(2.27)^{* *}\end{array}$ \\
\hline Constant & $\begin{array}{l}0.274 \\
(0.40)\end{array}$ & $\begin{array}{l}1.283 \\
(1.83)^{*}\end{array}$ & $\begin{array}{l}1.145 \\
(1.59)\end{array}$ & $\begin{array}{l}-0.321 \\
(0.33)\end{array}$ & $\begin{array}{l}1.305 \\
(1.31)\end{array}$ & $\begin{array}{l}1.087 \\
(1.08)\end{array}$ & $\begin{array}{l}-0.916 \\
(0.91)\end{array}$ & $\begin{array}{l}-0.481 \\
(0.47)\end{array}$ & $\begin{array}{l}-0.501 \\
(0.47)\end{array}$ \\
\hline Observations & 581 & 581 & 581 & 581 & 581 & 581 & 581 & 581 & 581 \\
\hline Pseudo $R^{2}$ & 0.20 & 0.21 & 0.23 & 0.26 & 0.28 & 0.30 & 0.17 & 0.17 & 0.18 \\
\hline
\end{tabular}

This table reports estimates of Poisson models on the number of subsidiaries divested by a firm from 1994 to 2002 . The sample consists of all firms listed on Thai Stock Exchange with at least one subsidiary at the beginning of the sample period. We further cut the time span into three periods: pre-crisis (1994 to 1996), crisis (1997 to 1999) and post-crisis (2000 to 2002). The unit of observation is a firm-period. We report estimates for the total number of subsidiaries divested (Total divestiture - columns (1) to (3)); the number of subsidiaries divested within the parent firm's core business (Core divestiture - columns (4) to (6)); and the number of subsidiaries divested within the parent firm's peripheral business (Peripheral divestiture - columns (7) to (9). Firm size is the logarithm of a firm's total assets. Change in ROA denotes the difference in ROA from the beginning and the end of a period. Current ratio is calculated as current assets divided by current liabilities. No. of subs is the number of subsidiaries a firm owns at the beginning of a period. No. of sectors is the number of sectors (two-digit SIC equivalent) that a firm owns at least one subsidiary. SubHHI denotes the Herfindahl index based on a firm's ownership shares in each of its subsidiaries. We classify firms into three ownership type based on total number of shares owned by their top ten shareholders. Family firms are mostly owned by domestic individuals with block shares; DI firms are mostly owned by domestic institutions and foreign firms are mostly owned by foreign investors. DI is omitted as benchmark for comparisons. All estimations control for sector fixed effects. Heteroskedasticity robust standard errors are used in calculating Z-statistics in parentheses.

* significant at $10 \%$, ** significant at $5 \%$, *** significant at $1 \%$.

are hardly affected during the crisis but significantly reduce their likelihood of increasing their number of subsidiaries after the crisis. Our findings support the hypothesis that domestic firms' operations are affected more than those of foreign firms by the financial crisis.

In Table 8, we re-estimate our divestiture models of Eq. (1) while controlling for the number of subsidiaries that are added during each period. The results show a positive relationship between subsidiary addition and divestiture in the peripheral segments, indicating that in the peripheral areas subsidiary divestiture is part of business churning as firms discard (presumably) bad projects and pursue promising new ones. Our earlier results with respect to ownership, reported in Table 4, are essentially unaffected.

\subsection{Effect of business groups among family firms}

While our classification of firms is intuitively appealing, it does not reveal substantial heterogeneity among domestic firms, especially in Thailand where many firms are likely to be part of a group of companies, linked together through common ownership, with ultimate ownership and control often lying with a single family. To examine the within-family-firm differences, 
Table 5

Logit estimation of subsidiary divestiture: subsidiary-level evidence.

\begin{tabular}{|c|c|c|c|c|c|c|c|c|c|}
\hline & \multicolumn{3}{|l|}{ Divestiture } & \multicolumn{3}{|c|}{ Core divestiture } & \multicolumn{3}{|c|}{ Peripheral divestiture } \\
\hline & $(1)$ & $(2)$ & (3) & $(4)$ & (5) & $(6)$ & (7) & $(8)$ & $(9)$ \\
\hline Firm size & $\begin{array}{l}-0.041 \\
(0.75)\end{array}$ & $\begin{array}{l}-0.140 \\
(2.41)^{* *}\end{array}$ & $\begin{array}{l}-0.131 \\
(2.23)^{* *}\end{array}$ & $\begin{array}{l}0.040 \\
(0.57)\end{array}$ & $\begin{array}{l}-0.091 \\
(1.18)\end{array}$ & $\begin{array}{l}-0.073 \\
(0.94)\end{array}$ & $\begin{array}{l}-0.111 \\
(1.39)\end{array}$ & $\begin{array}{l}-0.168 \\
(2.04)^{* *}\end{array}$ & $\begin{array}{l}-0.174 \\
(2.05)^{* *}\end{array}$ \\
\hline Change in ROA & $\begin{array}{l}-1.200 \\
(2.36)^{* *}\end{array}$ & $\begin{array}{l}-1.135 \\
(2.15)^{* *}\end{array}$ & $\begin{array}{l}-1.119 \\
(2.13)^{* *}\end{array}$ & $\begin{array}{l}-2.271 \\
(3.24)^{* * *}\end{array}$ & $\begin{array}{l}-2.252 \\
(3.02)^{* * *}\end{array}$ & $\begin{array}{l}-2.241 \\
(3.02)^{* * *}\end{array}$ & $\begin{array}{l}0.149 \\
(0.21)\end{array}$ & $\begin{array}{l}0.136 \\
(0.19)\end{array}$ & $\begin{array}{l}0.077 \\
(0.11)\end{array}$ \\
\hline Current ratio & $\begin{array}{l}-0.057 \\
(1.75)^{*}\end{array}$ & $\begin{array}{l}-0.045 \\
(1.29)\end{array}$ & $\begin{array}{l}-0.047 \\
(1.34)\end{array}$ & $\begin{array}{l}-0.099 \\
(2.23)^{* *}\end{array}$ & $\begin{array}{l}-0.127 \\
(2.65)^{* * *}\end{array}$ & $\begin{array}{l}-0.122 \\
(2.53)^{* *}\end{array}$ & $\begin{array}{l}-0.018 \\
(0.40)\end{array}$ & $\begin{array}{l}0.015 \\
(0.33)\end{array}$ & $\begin{array}{l}0.010 \\
(0.21)\end{array}$ \\
\hline SubHHI & $\begin{array}{l}-0.499 \\
(1.88)^{*}\end{array}$ & $\begin{array}{l}-0.484 \\
(1.85)^{*}\end{array}$ & $\begin{array}{l}-0.557 \\
(2.07)^{* *}\end{array}$ & $\begin{array}{l}-1.074 \\
(2.92)^{* * *}\end{array}$ & $\begin{array}{l}-1.128 \\
(3.09)^{* * *}\end{array}$ & $\begin{array}{l}-1.163 \\
(3.14)^{* * *}\end{array}$ & $\begin{array}{l}0.042 \\
(0.12)\end{array}$ & $\begin{array}{l}0.143 \\
(0.40)\end{array}$ & $\begin{array}{l}0.057 \\
(0.16)\end{array}$ \\
\hline No. of subs & $\begin{array}{l}-0.012 \\
(1.81)^{*}\end{array}$ & $\begin{array}{l}-0.021 \\
(3.02)^{* * *}\end{array}$ & $\begin{array}{l}-0.021 \\
(2.86)^{* * *}\end{array}$ & $\begin{array}{l}-0.002 \\
(0.21)\end{array}$ & $\begin{array}{l}-0.009 \\
(1.02)\end{array}$ & $\begin{array}{l}-0.007 \\
(0.78)\end{array}$ & $\begin{array}{l}-0.023 \\
(2.20)^{* *}\end{array}$ & $\begin{array}{l}-0.029 \\
(2.68)^{* * *}\end{array}$ & $\begin{array}{l}-0.029 \\
(2.60)^{* * *}\end{array}$ \\
\hline No. of sectors & $\begin{array}{l}-0.058 \\
(2.06)^{* *}\end{array}$ & $\begin{array}{l}0.054 \\
(1.64)\end{array}$ & $\begin{array}{l}0.050 \\
(1.47)\end{array}$ & $\begin{array}{l}-0.221 \\
(4.96)^{* * *}\end{array}$ & $\begin{array}{l}-0.078 \\
(1.58)\end{array}$ & $\begin{array}{l}-0.098 \\
(1.91)^{*}\end{array}$ & $\begin{array}{l}0.066 \\
(1.65)^{*}\end{array}$ & $\begin{array}{l}0.128 \\
(2.73)^{* * *}\end{array}$ & $\begin{array}{l}0.133 \\
(2.73)^{* * *}\end{array}$ \\
\hline SubSize & $\begin{array}{l}-0.020 \\
(0.89)\end{array}$ & $\begin{array}{l}-0.004 \\
(0.17)\end{array}$ & $\begin{array}{l}-0.003 \\
(0.11)\end{array}$ & $\begin{array}{l}-0.066 \\
(2.28)^{* *}\end{array}$ & $\begin{array}{l}-0.046 \\
(1.53)\end{array}$ & $\begin{array}{l}-0.045 \\
(1.50)\end{array}$ & $\begin{array}{l}0.035 \\
(1.03)\end{array}$ & $\begin{array}{l}0.045 \\
(1.29)\end{array}$ & $\begin{array}{l}0.047 \\
(1.33)\end{array}$ \\
\hline SubOWN & $\begin{array}{l}-1.137 \\
(6.33)^{* * *}\end{array}$ & $\begin{array}{l}-1.026 \\
(5.66)^{* * *}\end{array}$ & $\begin{array}{l}-1.013 \\
(5.55)^{* * *}\end{array}$ & $\begin{array}{l}-0.855 \\
(3.62)^{* * *}\end{array}$ & $\begin{array}{l}-0.689 \\
(2.90)^{* * *}\end{array}$ & $\begin{array}{l}-0.673 \\
(2.81)^{* * *}\end{array}$ & $\begin{array}{l}-1.303 \\
(5.08)^{* * *}\end{array}$ & $\begin{array}{l}-1.225 \\
(4.76)^{* * *}\end{array}$ & $\begin{array}{l}-1.234 \\
(4.76)^{* * *}\end{array}$ \\
\hline Family & $\begin{array}{l}0.118 \\
(0.98)\end{array}$ & & $\begin{array}{l}0.172 \\
(0.97)\end{array}$ & $\begin{array}{l}0.101 \\
(0.64)\end{array}$ & & $\begin{array}{l}0.200 \\
(0.94)\end{array}$ & $\begin{array}{l}0.156 \\
(0.92)\end{array}$ & & $\begin{array}{l}0.073 \\
(0.27)\end{array}$ \\
\hline Foreign & $\begin{array}{l}-0.335 \\
(1.36)\end{array}$ & & $\begin{array}{l}-0.755 \\
(1.90)^{*}\end{array}$ & $\begin{array}{l}-1.132 \\
(2.57)^{* *}\end{array}$ & & $\begin{array}{l}-0.963 \\
(1.78)^{*}\end{array}$ & $\begin{array}{l}0.189 \\
(0.63)\end{array}$ & & $\begin{array}{l}-0.371 \\
(0.67)\end{array}$ \\
\hline Crisis & & $\begin{array}{l}-0.573 \\
(4.13)^{* * *}\end{array}$ & & & $\begin{array}{l}-0.717 \\
(3.88)^{* * *}\end{array}$ & & & $\begin{array}{l}-0.179 \\
(0.91)\end{array}$ & \\
\hline Post-crisis & & $\begin{array}{l}-1.162 \\
(7.43)^{* * *}\end{array}$ & & & $\begin{array}{l}-1.340 \\
(6.41)^{* * *}\end{array}$ & & & $\begin{array}{l}-0.734 \\
(3.28)^{* * *}\end{array}$ & \\
\hline Crisis* Family & & & $\begin{array}{l}-0.913 \\
(5.13)^{* * *}\end{array}$ & & & $\begin{array}{l}-0.981 \\
(4.23)^{* * *}\end{array}$ & & & $\begin{array}{l}-0.448 \\
(1.74)^{*}\end{array}$ \\
\hline Crisis* Foreign & & & $\begin{array}{l}0.595 \\
(1.15)\end{array}$ & & & $\begin{array}{l}-0.799 \\
(0.70)\end{array}$ & & & $\begin{array}{l}0.908 \\
(1.42)\end{array}$ \\
\hline Crisis*DI & & & $\begin{array}{l}-0.309 \\
(1.56)\end{array}$ & & & $\begin{array}{l}-0.303 \\
(1.16)\end{array}$ & & & $\begin{array}{l}-0.095 \\
(0.34)\end{array}$ \\
\hline Post-crisis*Family & & & $\begin{array}{l}-0.971 \\
(5.16)^{* * *}\end{array}$ & & & $\begin{array}{l}-1.110 \\
(4.43)^{* * *}\end{array}$ & & & $\begin{array}{l}-0.489 \\
(1.82)^{*}\end{array}$ \\
\hline Post-crisis* Foreign & & & $\begin{array}{l}-0.688 \\
(1.14)\end{array}$ & & & $\begin{array}{l}-1.259 \\
(1.10)\end{array}$ & & & $\begin{array}{l}-0.431 \\
(0.58)\end{array}$ \\
\hline Post-crisis* DI & & & $\begin{array}{l}-1.628 \\
(6.16)^{* * *}\end{array}$ & & & $\begin{array}{l}-1.704 \\
(4.79)^{* * *}\end{array}$ & & & $\begin{array}{l}-1.329 \\
(3.52)^{* * *}\end{array}$ \\
\hline Constant & $\begin{array}{l}0.339 \\
(0.40)\end{array}$ & $\begin{array}{l}1.769 \\
(2.02)^{* *}\end{array}$ & $\begin{array}{l}1.550 \\
(1.73)^{*}\end{array}$ & $\begin{array}{l}-0.502 \\
(0.45)\end{array}$ & $\begin{array}{l}1.300 \\
(1.11)\end{array}$ & $\begin{array}{l}0.895 \\
(0.76)\end{array}$ & $\begin{array}{l}-0.706 \\
(0.58)\end{array}$ & $\begin{array}{l}0.100 \\
(0.08)\end{array}$ & $\begin{array}{l}0.176 \\
(0.14)\end{array}$ \\
\hline Observations & 3625 & 3625 & 3625 & 3625 & 3625 & 3625 & 3625 & 3625 & 3625 \\
\hline Pseudo $R^{2}$ & 0.06 & 0.08 & 0.09 & 0.11 & 0.12 & 0.13 & 0.06 & 0.06 & 0.07 \\
\hline
\end{tabular}

This table reports estimates of Logit models on the probability of a subsidiary divested from 1994 to 2002 . The sample consists of all firms listed on Thai Stock Exchange with at least one subsidiary at the beginning of the sample period. We further cut the time span into three periods: pre-crisis (1994 to 1996), crisis (1997 to 1999) and post-crisis (2000 to 2002). The unit of observation is a subsidiary-period. We report estimates for the probability of a subsidiary divested (Divestiture - columns (1) to (3)); the probability of a subsidiary divested within the parent firm's core business (Core divestiture - columns (4) to (6)); and the probability of a subsidiary divested within the parent firm's peripheral business (Peripheral divestiture - columns (7) to (9). Firm size is the logarithm of a firm's total assets. Change in ROA denotes the difference in ROA from the beginning and the end of a period. Current ratio is calculated as current assets divided by current liabilities. No. of subs is the number of subsidiaries a firm owns at the beginning of a period. No. of Sectors is the number of sectors (two-digit SIC equivalent) that a firm owns at least one subsidiary. SubHHI denotes the Herfindahl index based on a firm's ownership shares in each of its subsidiaries. Subsize is the logarithm of a subsidiary's paid-in capital. SubOWN is the percentage of shares owned by its parent firm. We classify firms into three ownership type based on total number of shares owned by their top ten shareholders. Family firms are mostly owned by domestic individuals with block shares; DI firms are mostly owned by domestic institutions and foreign firms are mostly owned by foreign investors. DI is omitted as benchmark for comparisons. All estimations control for sector fixed effects. Heteroskedasticity robust standard errors are used in calculating $Z$-statistics in parentheses.

$*$ significant at $10 \%, * *$ significant at $5 \%$, *** significant at $1 \%$.

we distinguish a normal family firm from a family firm affiliated with one of the 150 leading Thai business groups. We re-estimate the divestiture and acquisition models within the sample of family firms with the addition of a dummy variable equal to one if a family is affiliated with a business group (BG) and zero otherwise. We expect firms connected to business groups to be able to use financial/political resources possessed by the group and therefore be less constrained by the crisis.

Table 9 reports estimation of divestiture and expansion within the sample of family firms. Columns 1 and 4 suggest that on average family firms affiliated with business groups are similar to non-affiliated firms in terms of divestiture, but are more active in acquisition. When we interact the Business Group dummy with crisis (columns 3 and 6 ), we find that these connected family firms are less negatively affected by the crisis in their business churning behavior - they divest more subsidiaries before the crisis, fewer during the crisis and about the same after the crisis. Moreover, they exhibit greater expansion in all three periods. 
Table 6

Poisson estimation of subsidiary addition: firm-level evidence.

\begin{tabular}{|c|c|c|c|c|c|c|c|c|c|}
\hline & \multicolumn{3}{|c|}{ Total expansion } & \multicolumn{3}{|c|}{ Core expansion } & \multicolumn{3}{|c|}{ Peripheral expansion } \\
\hline & $(1)$ & $(2)$ & (3) & $(4)$ & (5) & (6) & $(7)$ & $(8)$ & (9) \\
\hline Firm size & $\begin{array}{l}0.303 \\
(9.31)^{* * *}\end{array}$ & $\begin{array}{l}0.228 \\
(6.69)^{* * *}\end{array}$ & $\begin{array}{l}0.242 \\
(7.09)^{* * *}\end{array}$ & $\begin{array}{l}0.308 \\
(7.24)^{\text {*** }}\end{array}$ & $\begin{array}{l}0.247 \\
(5.66)^{* * *}\end{array}$ & $\begin{array}{l}0.260 \\
(5.95)^{* * *}\end{array}$ & $\begin{array}{l}0.291 \\
(5.71)^{* * *}\end{array}$ & $\begin{array}{l}0.208 \\
(3.78)^{* * *}\end{array}$ & $\begin{array}{l}0.219 \\
(3.96)^{* * *}\end{array}$ \\
\hline Change in ROA & $\begin{array}{l}-1.102 \\
(3.40)^{* * *}\end{array}$ & $\begin{array}{l}0.045 \\
(0.12)\end{array}$ & $\begin{array}{l}-0.005 \\
(0.01)\end{array}$ & $\begin{array}{l}-1.293 \\
(3.03)^{* * *}\end{array}$ & $\begin{array}{l}-0.239 \\
(0.50)\end{array}$ & $\begin{array}{l}-0.253 \\
(0.53)\end{array}$ & $\begin{array}{l}-0.659 \\
(1.27)\end{array}$ & $\begin{array}{l}0.451 \\
(0.77)\end{array}$ & $\begin{array}{l}0.427 \\
(0.73)\end{array}$ \\
\hline Current ratio & $\begin{array}{l}0.055 \\
(3.36)^{* * *}\end{array}$ & $\begin{array}{l}0.055 \\
(3.26)^{* * *}\end{array}$ & $\begin{array}{l}0.055 \\
(3.23)^{* * *}\end{array}$ & $\begin{array}{l}0.078 \\
(4.04)^{* * *}\end{array}$ & $\begin{array}{l}0.073 \\
(3.62)^{* * *}\end{array}$ & $\begin{array}{l}0.071 \\
(3.48)^{* * *}\end{array}$ & $\begin{array}{l}0.001 \\
(0.04)\end{array}$ & $\begin{array}{l}0.024 \\
(0.75)\end{array}$ & $\begin{array}{l}0.028 \\
(0.86)\end{array}$ \\
\hline SubHHI & $\begin{array}{l}-1.079 \\
(7.44)^{* * *}\end{array}$ & $\begin{array}{l}-0.892 \\
(6.35)^{* * *}\end{array}$ & $\begin{array}{l}-0.868 \\
(6.12)^{* * *}\end{array}$ & $\begin{array}{l}-1.567 \\
(7.68)^{* * *}\end{array}$ & $\begin{array}{l}-1.388 \\
(6.96)^{* * *}\end{array}$ & $\begin{array}{l}-1.340 \\
(6.67)^{* * *}\end{array}$ & $\begin{array}{l}-0.585 \\
(2.83)^{* * *}\end{array}$ & $\begin{array}{l}-0.417 \\
(2.09)^{* *}\end{array}$ & $\begin{array}{l}-0.412 \\
(2.05)^{* *}\end{array}$ \\
\hline No. of subs & $\begin{array}{l}0.043 \\
(10.93)^{* * *}\end{array}$ & $\begin{array}{l}0.028 \\
(7.11)^{* * *}\end{array}$ & $\begin{array}{l}0.028 \\
(7.02)^{* * *}\end{array}$ & $\begin{array}{l}0.026 \\
(4.49)^{* * *}\end{array}$ & $\begin{array}{l}0.015 \\
(2.66)^{* * *}\end{array}$ & $\begin{array}{l}0.016 \\
(2.63)^{* * *}\end{array}$ & $\begin{array}{l}0.058 \\
(10.56)^{* * *}\end{array}$ & $\begin{array}{l}0.037 \\
(6.66)^{* * *}\end{array}$ & $\begin{array}{l}0.037 \\
(6.43)^{\text {*** }}\end{array}$ \\
\hline No. of sectors & $\begin{array}{l}-0.242 \\
(11.93)^{\text {*** }}\end{array}$ & $\begin{array}{l}-0.057 \\
(2.65)^{* * *}\end{array}$ & $\begin{array}{l}-0.064 \\
(2.88)^{* * *}\end{array}$ & $\begin{array}{l}-0.238 \\
(7.72)^{* * *}\end{array}$ & $\begin{array}{l}-0.079 \\
(2.42)^{* *}\end{array}$ & $\begin{array}{l}-0.088 \\
(2.67)^{* * *}\end{array}$ & $\begin{array}{l}-0.244 \\
(9.12)^{* * *}\end{array}$ & $\begin{array}{l}-0.017 \\
(0.56)\end{array}$ & $\begin{array}{l}-0.017 \\
(0.55)\end{array}$ \\
\hline Family & $\begin{array}{l}0.296 \\
(3.76)^{* * *}\end{array}$ & & $\begin{array}{l}0.242 \\
(2.65)^{* * *}\end{array}$ & $\begin{array}{l}0.324 \\
(3.14)^{* * *}\end{array}$ & & $\begin{array}{l}0.257 \\
(2.09)^{* *}\end{array}$ & $\begin{array}{l}0.269 \\
(2.18)^{* *}\end{array}$ & & $\begin{array}{l}0.193 \\
(1.40)\end{array}$ \\
\hline Foreign & $\begin{array}{l}-0.136 \\
(1.07)\end{array}$ & & $\begin{array}{l}-0.334 \\
(2.19)^{* *}\end{array}$ & $\begin{array}{l}-0.157 \\
(0.88)\end{array}$ & & $\begin{array}{l}-0.370 \\
(1.65)^{*}\end{array}$ & $\begin{array}{l}-0.086 \\
(0.47)\end{array}$ & & $\begin{array}{l}-0.344 \\
(1.64)\end{array}$ \\
\hline Crisis & & $\begin{array}{l}-1.407 \\
(13.78)^{* * *}\end{array}$ & & & $\begin{array}{l}-1.310 \\
(9.59)^{* * *}\end{array}$ & & & $\begin{array}{l}-1.548 \\
(9.84)^{* * *}\end{array}$ & \\
\hline Post-crisis & & $\begin{array}{l}-1.160 \\
(12.33)^{* * *}\end{array}$ & & & $\begin{array}{l}-0.704 \\
(6.34)^{* * *}\end{array}$ & & & $\begin{array}{l}-2.097 \\
(10.79)^{* * *}\end{array}$ & \\
\hline Crisis*Family & & & $\begin{array}{l}-1.485 \\
(11.39)^{\text {*** }}\end{array}$ & & & $\begin{array}{l}-1.256 \\
(7.56)^{* * *}\end{array}$ & & & $\begin{array}{l}-1.798 \\
(8.40)^{* * *}\end{array}$ \\
\hline Crisis* Foreign & & & $\begin{array}{l}-0.592 \\
(2.15)^{* *}\end{array}$ & & & $\begin{array}{l}-0.456 \\
(1.15)\end{array}$ & & & $\begin{array}{l}-0.789 \\
(2.05)^{* *}\end{array}$ \\
\hline Crisis* DI & & & $\begin{array}{l}-1.517 \\
(9.10)^{* * *}\end{array}$ & & & $\begin{array}{l}-1.709 \\
(6.73)^{* * *}\end{array}$ & & & $\begin{array}{l}-1.472 \\
(6.36)^{* * *}\end{array}$ \\
\hline Post-crisis* Family & & & $\begin{array}{l}-1.146 \\
(9.36)^{* * *}\end{array}$ & & & $\begin{array}{l}-0.696 \\
(4.83)^{* * *}\end{array}$ & & & $\begin{array}{l}-2.096 \\
(8.17)^{* * *}\end{array}$ \\
\hline Post-crisis* Foreign & & & $\begin{array}{l}-1.030 \\
(3.57)^{* * *}\end{array}$ & & & $\begin{array}{l}-0.533 \\
(1.48)\end{array}$ & & & $\begin{array}{l}-1.865 \\
(3.48)^{* * *}\end{array}$ \\
\hline Post-crisis*DI & & & $\begin{array}{l}-1.190 \\
(8.03)^{* * *}\end{array}$ & & & $\begin{array}{l}-0.722 \\
(4.19)^{* * *}\end{array}$ & & & $\begin{array}{l}-2.188 \\
(6.89)^{* * *}\end{array}$ \\
\hline Constant & $\begin{array}{l}-3.390 \\
(6.80)^{* * *}\end{array}$ & $\begin{array}{l}-1.841 \\
(3.64)^{* * *}\end{array}$ & $\begin{array}{l}-2.216 \\
(4.28)^{* * *}\end{array}$ & $\begin{array}{l}-3.919 \\
(5.97)^{* * *}\end{array}$ & $\begin{array}{l}-2.618 \\
(3.99)^{* * *}\end{array}$ & $\begin{array}{l}-3.002 \\
(4.46)^{* * *}\end{array}$ & $\begin{array}{l}-4.140 \\
(5.35)^{* * *}\end{array}$ & $\begin{array}{l}-2.444 \\
(3.04)^{* * *}\end{array}$ & $\begin{array}{l}-2.728 \\
(3.31)^{* * *}\end{array}$ \\
\hline Observations & 581 & 581 & 581 & 581 & 581 & 581 & 581 & 581 & 581 \\
\hline Pseudo $R^{2}$ & 0.26 & 0.35 & 0.36 & 0.25 & 0.29 & 0.30 & 0.26 & 0.37 & 0.38 \\
\hline
\end{tabular}

This table reports estimates of Poisson models on the number of subsidiaries acquired by a firm from 1994 to 2002 . The sample consists of all firms listed on Thai Stock Exchange with at least one subsidiary at the beginning of the sample period. We further cut the time span into three periods: pre-crisis (1994 to 1996), crisis (1997 to 1999) and post-crisis (2000 to 2002). The unit of observation is a firm-period. We report estimates for the total number of subsidiaries added (Total expansion - columns (1) to (3)); the number of subsidiaries added within the parent firm's core business (Core expansion - columns (4) to (6)); and the number of subsidiaries added within the parent firm's peripheral business (Peripheral expansion - columns (7) to (9). Firm size is the logarithm of a firm's total assets. Change in ROA denotes the difference in ROA from the beginning and the end of a period. Current ratio is calculated as current assets divided by current liabilities. No. of subs is the number of subsidiaries a firm owns at the beginning of a period. No. of Sectors is the number of sectors (two-digit SIC equivalent) that a firm owns at least one subsidiary. SubHHI denotes the Herfindahl index based on a firm's ownership shares in each of its subsidiaries. We classify firms into three ownership type based on total number of shares owned by their top ten shareholders. Family firms are mostly owned by domestic individuals with block shares; DI firms are mostly owned by domestic institutions and foreign firms are mostly owned by foreign investors. DI is omitted as benchmark for comparisons. All estimations control for sector fixed effects. Heteroskedasticity robust standard errors are used in calculating Z-statistics in parentheses.

$*$ significant at $10 \%$, ** significant at $5 \%$, *** significant at $1 \%$.

\section{Discussion and conclusion}

In this study, we use parent- and subsidiary-level data for publicly listed firms in Thailand to investigate how firms restructure their business portfolios, in terms of divestitures and acquisitions, before, during, and after the 1997 Asian Financial Crisis. We show that during the crisis (1) foreign firms' restructuring behavior is the least affected; (2) domestic firms owned by families and domestic institutions (DI) behave similarly to one another, with the DI firms responding to the crisis with a lag; (3) domestic firms do not increase divestiture in their peripheral segments to improve operational focus or to obtain cash in a credit crunch; they actually reduce divestiture in core segments; and (4) domestic firms significantly reduce the acquisition of new subsidiaries but the reduction in divestiture dominates the reduction in acquisition.

Our results challenge the traditional explanations for divestiture such as corporate governance, operational refocus and financial constraints. They indicate that in the great uncertainty of a crisis, domestic firms - especially those affiliated with business groups or owned by other large firms - are able to hold onto their core assets to avoid fire-sale. In essence, they act more conservatively than their foreign counterparts in altering their business portfolios. 
Table 7

Logit estimation of subsidiary net addition: firm-level evidence.

\begin{tabular}{|c|c|c|c|c|c|c|c|c|c|}
\hline & \multicolumn{3}{|c|}{ Net addition } & \multicolumn{3}{|c|}{ Net addition in core } & \multicolumn{3}{|c|}{ Net addition in peripheral } \\
\hline & $(1)$ & $(2)$ & (3) & $(4)$ & (5) & (6) & (7) & (8) & $(9)$ \\
\hline Firm size & $\begin{array}{l}0.353 \\
(3.67)^{* * *}\end{array}$ & $\begin{array}{l}0.315 \\
(3.14)^{* * *}\end{array}$ & $\begin{array}{l}0.314 \\
(3.14)^{* * *}\end{array}$ & $\begin{array}{l}0.398 \\
(4.02)^{* * *}\end{array}$ & $\begin{array}{l}0.382 \\
(3.60)^{* * *}\end{array}$ & $\begin{array}{l}0.405 \\
(3.83)^{\text {*** }}\end{array}$ & $\begin{array}{l}0.303 \\
(2.88)^{* * *}\end{array}$ & $\begin{array}{l}0.225 \\
(1.89)^{*}\end{array}$ & $\begin{array}{l}0.226 \\
(1.90)^{*}\end{array}$ \\
\hline Change in $\mathrm{ROA}$ & $\begin{array}{l}-0.497 \\
(0.50)\end{array}$ & $\begin{array}{l}0.668 \\
(0.64)\end{array}$ & $\begin{array}{l}0.757 \\
(0.70)\end{array}$ & $\begin{array}{l}-1.157 \\
(1.08)\end{array}$ & $\begin{array}{l}-0.149 \\
(0.13)\end{array}$ & $\begin{array}{l}-0.046 \\
(0.04)\end{array}$ & $\begin{array}{l}-1.056 \\
(1.08)\end{array}$ & $\begin{array}{l}0.347 \\
(0.34)\end{array}$ & $\begin{array}{l}0.256 \\
(0.24)\end{array}$ \\
\hline Current ratio & $\begin{array}{l}-0.049 \\
(0.94)\end{array}$ & $\begin{array}{l}-0.052 \\
(0.92)\end{array}$ & $\begin{array}{l}-0.055 \\
(0.96)\end{array}$ & $\begin{array}{l}0.078 \\
(1.48)\end{array}$ & $\begin{array}{l}0.059 \\
(1.06)\end{array}$ & $\begin{array}{l}0.058 \\
(1.02)\end{array}$ & $\begin{array}{l}0.027 \\
(0.46)\end{array}$ & $\begin{array}{l}0.066 \\
(0.97)\end{array}$ & $\begin{array}{l}0.077 \\
(1.15)\end{array}$ \\
\hline SubHHI & $\begin{array}{l}-0.595 \\
(1.45)\end{array}$ & $\begin{array}{l}-0.529 \\
(1.28)\end{array}$ & $\begin{array}{l}-0.474 \\
(1.11)\end{array}$ & $\begin{array}{l}-0.970 \\
(2.16)^{* *}\end{array}$ & $\begin{array}{l}-0.960 \\
(2.22)^{* *}\end{array}$ & $\begin{array}{c}-0.858 \\
(1.93)^{*}\end{array}$ & $\begin{array}{l}-1.093 \\
(2.35)^{* *}\end{array}$ & $\begin{array}{l}-1.078 \\
(2.26)^{* *}\end{array}$ & $\frac{-1.067}{(2.21)^{* *}}$ \\
\hline No. of subs & $\begin{array}{l}0.030 \\
(1.55)\end{array}$ & $\begin{array}{l}0.008 \\
(0.44)\end{array}$ & $\begin{array}{l}0.009 \\
(0.52)\end{array}$ & $\begin{array}{l}-0.015 \\
(0.85)\end{array}$ & $\begin{array}{l}-0.037 \\
(2.07)^{* *}\end{array}$ & $\begin{array}{l}-0.039 \\
(2.14)^{* *}\end{array}$ & $\begin{array}{l}0.046 \\
(2.42)^{* *}\end{array}$ & $\begin{array}{l}0.021 \\
(1.16)\end{array}$ & $\begin{array}{l}0.021 \\
(1.14)\end{array}$ \\
\hline No. of sectors & $\begin{array}{l}-0.337 \\
(3.91)^{* * *}\end{array}$ & $\begin{array}{l}-0.116 \\
(1.44)\end{array}$ & $\begin{array}{l}-0.114 \\
(1.36)\end{array}$ & $\begin{array}{l}-0.117 \\
(1.39)\end{array}$ & $\begin{array}{l}0.083 \\
(0.98)\end{array}$ & $\begin{array}{l}0.083 \\
(0.97)\end{array}$ & $\begin{array}{l}-0.435 \\
(4.88)^{* * *}\end{array}$ & $\begin{array}{c}-0.150 \\
(1.78)^{*}\end{array}$ & $\begin{array}{l}-0.146 \\
(1.70)^{*}\end{array}$ \\
\hline Family & $\begin{array}{l}0.039 \\
(0.18)\end{array}$ & & $\begin{array}{l}0.100 \\
(0.30)\end{array}$ & $\begin{array}{l}0.253 \\
(1.11)\end{array}$ & & $\begin{array}{l}-0.043 \\
(0.13)\end{array}$ & $\begin{array}{l}0.114 \\
(0.47)\end{array}$ & & $\begin{array}{l}0.256 \\
(0.77)\end{array}$ \\
\hline Foreign & $\begin{array}{l}-0.041 \\
(0.12)\end{array}$ & & $\begin{array}{l}-0.685 \\
(1.41)\end{array}$ & $\begin{array}{l}-0.107 \\
(0.31)\end{array}$ & & $\begin{array}{l}-0.903 \\
(1.89)^{*}\end{array}$ & $\begin{array}{l}-0.314 \\
(0.79)\end{array}$ & & $\begin{array}{l}-0.364 \\
(0.71)\end{array}$ \\
\hline Crisis & & $\begin{array}{l}-1.712 \\
(6.53)^{* * *}\end{array}$ & & & $\begin{array}{l}-1.795 \\
(6.22)^{* * *}\end{array}$ & & & $\begin{array}{l}-1.806 \\
(6.04)^{* * *}\end{array}$ & \\
\hline Post-crisis & & $\begin{array}{l}-1.255 \\
(5.00)^{* * *}\end{array}$ & & & $\begin{array}{l}-0.804 \\
(3.19)^{* * *}\end{array}$ & & & $\begin{array}{l}-2.003 \\
(6.36)^{* * *}\end{array}$ & \\
\hline Crisis* Family & & & $\begin{array}{l}-2.025 \\
(5.53)^{* * *}\end{array}$ & & & $\begin{array}{l}-1.711 \\
(4.58)^{* * *}\end{array}$ & & & $\begin{array}{l}-2.271 \\
(5.01)^{* * *}\end{array}$ \\
\hline Crisis* Foreign & & & $\begin{array}{l}-0.261 \\
(0.40)\end{array}$ & & & $\begin{array}{l}-0.660 \\
(0.87)\end{array}$ & & & $\begin{array}{l}-0.888 \\
(1.21)\end{array}$ \\
\hline Crisis* DI & & & $\begin{array}{l}-1.825 \\
(4.61)^{* * *}\end{array}$ & & & $\begin{array}{l}-2.295 \\
(4.84)^{* * *}\end{array}$ & & & $\begin{array}{l}-1.602 \\
(3.70)^{* * *}\end{array}$ \\
\hline Post-crisis*Family & & & $\begin{array}{l}-1.479 \\
(4.07)^{* * *}\end{array}$ & & & $\begin{array}{l}-0.662 \\
(1.91)^{*}\end{array}$ & & & $\begin{array}{l}-2.150 \\
(4.66)^{* * *}\end{array}$ \\
\hline Post-crisis* Foreign & & & $\begin{array}{l}-0.584 \\
(0.93)\end{array}$ & & & $\begin{array}{l}-0.040 \\
(0.06)\end{array}$ & & & $\begin{array}{l}-2.775 \\
(2.45)^{* *}\end{array}$ \\
\hline Post-crisis $*$ DI & & & $\begin{array}{l}-1.236 \\
(3.16)^{* * *}\end{array}$ & & & $\begin{array}{l}-1.182 \\
(2.90)^{* * *}\end{array}$ & & & $\begin{array}{l}-1.684 \\
(3.70)^{* * *}\end{array}$ \\
\hline Observations & 581 & 581 & 581 & 581 & 581 & 581 & 581 & 581 & 581 \\
\hline Pseudo $R^{2}$ & 0.10 & 0.17 & 0.18 & 0.11 & 0.17 & 0.18 & 0.12 & 0.21 & 0.22 \\
\hline
\end{tabular}

This table reports estimates of Logit models on the probability of subsidiary net addition by a firm from 1994 to 2002 . Net addition is a dummy variable equal to one if the number of subsidiaries acquired by a firm exceeds the number of subsidiaries divested. The sample consists of all firms listed on Thai Stock Exchange with at least one subsidiary at the beginning of the sample period. We further cut the time span into three periods: pre-crisis (1994 to 1996 ), crisis (1997 to 1999) and post-crisis (2000 to 2002). The unit of observation is a firm-period. We report estimates for the probability of net addition (Net addition - columns ( 1 ) to (3)); the probability of net addition within the parent firm's core business (Net addition in core - columns (4) to (6)); and the number of subsidiaries added within the parent firm's peripheral business (Net addition in peripheral - columns (7) to (9). Firm size is the logarithm of a firm's total assets. Change in ROA denotes the difference in ROA from the beginning and the end of a period. Current ratio is calculated as current assets divided by current liabilities. No. of subs is the number of subsidiaries a firm owns at the beginning of a period. No. of Sectors is the number of sectors (two-digit SIC equivalent) that a firm owns at least one subsidiary. SubHHI denotes the Herfindahl index based on a firm's ownership shares in each of its subsidiaries. We classify firms into three ownership type based on total number of shares owned by their top ten shareholders. Family firms are mostly owned by domestic individuals with block shares; DI firms are mostly owned by domestic institutions and foreign firms are mostly owned by foreign investors. DI is omitted as benchmark for comparisons. All estimations control for sector fixed effects. Heteroskedasticity robust standard errors are used in calculating Z-statistics in parentheses.

$*$ significant at $10 \%, * *$ significant at $5 \%$, *** significant at $1 \%$.

Our finding that family firms do not differ significantly from DI firms in corporate restructuring is worthy of further discussion. Despite their unique governance structure, the advantages and disadvantages of family firms have been a subject of major academic debate. The widely held perception that family firms are an inefficient organizational form used by families to pursue private benefits rather than firm profitability is at odds with the prevalence of family firms in both emerging and developed economies, as studied in Claessens et al. (2000) and La Porta et al. (1999). Adding to the puzzle, empirical studies comparing the performance of family firms and non-family firms are inconclusive. For example, Anderson and Reeb (2003a) report that family firms in the U.S. perform better than non-family firms, whereas Holderness and Sheehan (1988) find the opposite. The same inconclusiveness is witnessed in other countries (see Claessens et al., 2002; Morck et al., 2004). Our data show that under normal circumstances (i.e., before the financial crisis), family firms in our sample have similar performance to firms owned by domestic institutions (Fig. 2). It is likely that the strength and weakness of family ownership as a governance form offset each other, and family firms are as efficient as other domestic firms in equilibrium. This conjecture is tested primarily by the crisis that acts as an exogenous shock. The similarity between family and DI firms' portfolio restructuring choices before, during, and after the crisis provides micro-level, behavioral support for the suggestions that the two types of firms behave and perform similarly.

The paper examines whether family firms divest their core assets during the crisis to tunnel money (presumably to their family members or to other private businesses owned by the family). Our evidence is preliminary in that it only looks at the number of 
Table 8

Poisson estimation of subsidiary divestiture controlling for subsidiary addition.

\begin{tabular}{|c|c|c|c|c|c|c|c|c|c|}
\hline & \multicolumn{3}{|c|}{ Total divestiture } & \multicolumn{3}{|c|}{ Core divestiture } & \multicolumn{3}{|c|}{ Peripheral divestiture } \\
\hline & $(1)$ & $(2)$ & (3) & $(4)$ & $(5)$ & $(6)$ & $(7)$ & $(8)$ & (9) \\
\hline Total expansion & $\begin{array}{l}0.028 \\
(2.68)^{\text {*** }}\end{array}$ & $\begin{array}{l}0.013 \\
(1.11)\end{array}$ & $\begin{array}{l}0.026 \\
(1.29)\end{array}$ & $\begin{array}{l}0.025 \\
(1.77)^{*}\end{array}$ & $\begin{array}{l}-0.007 \\
(0.21)\end{array}$ & $\begin{array}{l}-0.006 \\
(0.37)\end{array}$ & $\begin{array}{l}0.042 \\
(2.52)^{* *}\end{array}$ & $\begin{array}{l}0.048 \\
(2.69)^{* * *}\end{array}$ & $\begin{array}{l}0.051 \\
(2.81)^{* * *}\end{array}$ \\
\hline Firm size & $\begin{array}{l}-0.010 \\
(0.22)\end{array}$ & $\begin{array}{l}-0.048 \\
(1.00)\end{array}$ & $\begin{array}{l}-0.059 \\
(0.84)\end{array}$ & $\begin{array}{l}0.009 \\
(0.15)\end{array}$ & $\begin{array}{l}-0.047 \\
(0.39)\end{array}$ & $\begin{array}{l}-0.038 \\
(0.58)\end{array}$ & $\begin{array}{l}-0.009 \\
(0.14)\end{array}$ & $\begin{array}{l}-0.034 \\
(0.50)\end{array}$ & $\begin{array}{l}-0.031 \\
(0.44)\end{array}$ \\
\hline Change in ROA & $\begin{array}{l}-0.907 \\
(2.21)^{* *}\end{array}$ & $\begin{array}{l}-0.792 \\
(1.93)^{*}\end{array}$ & $\begin{array}{l}-0.748 \\
(1.20)\end{array}$ & $\begin{array}{l}-2.435 \\
(4.11)^{* * *}\end{array}$ & $\begin{array}{l}-2.120 \\
(2.47)^{* *}\end{array}$ & $\begin{array}{l}-2.129 \\
(3.61)^{* * *}\end{array}$ & $\begin{array}{l}0.626 \\
(1.06)\end{array}$ & $\begin{array}{l}0.452 \\
(0.78)\end{array}$ & $\begin{array}{l}0.402 \\
(0.70)\end{array}$ \\
\hline Current ratio & $\begin{array}{l}-0.078 \\
(2.64)^{* * *}\end{array}$ & $\begin{array}{l}-0.070 \\
(2.33)^{* *}\end{array}$ & $\begin{array}{l}-0.035 \\
(0.78)\end{array}$ & $\begin{array}{l}-0.122 \\
(2.84)^{* * *}\end{array}$ & $\begin{array}{l}-0.125 \\
(1.80)^{*}\end{array}$ & $\begin{array}{l}-0.119 \\
(2.63)^{* * *}\end{array}$ & $\begin{array}{l}-0.047 \\
(1.14)\end{array}$ & $\begin{array}{l}-0.035 \\
(0.86)\end{array}$ & $\begin{array}{l}-0.034 \\
(0.82)\end{array}$ \\
\hline SubHHI & $\begin{array}{l}-1.792 \\
(7.54)^{* * *}\end{array}$ & $\begin{array}{l}-1.797 \\
(7.56)^{* * *}\end{array}$ & $\begin{array}{l}-2.111 \\
(6.51)^{* * *}\end{array}$ & $\begin{array}{l}-2.282 \\
(6.48)^{* * *}\end{array}$ & $\begin{array}{l}-2.367 \\
(3.86)^{* * *}\end{array}$ & $\begin{array}{l}-2.329 \\
(6.54)^{* * *}\end{array}$ & $\begin{array}{l}-1.352 \\
(4.14)^{* * *}\end{array}$ & $\begin{array}{l}-1.340 \\
(4.12)^{* * *}\end{array}$ & $\begin{array}{l}-1.340 \\
(4.09)^{* * *}\end{array}$ \\
\hline No. of subs & $\begin{array}{l}0.024 \\
(3.88)^{* * *}\end{array}$ & $\begin{array}{l}0.024 \\
(3.91)^{* * *}\end{array}$ & $\begin{array}{l}0.046 \\
(3.24)^{* * *}\end{array}$ & $\begin{array}{l}0.042 \\
(5.23)^{* * *}\end{array}$ & $\begin{array}{l}0.043 \\
(2.87)^{* * *}\end{array}$ & $\begin{array}{l}0.045 \\
(5.34)^{\text {*** }}\end{array}$ & $\begin{array}{l}-0.001 \\
(0.11)\end{array}$ & $\begin{array}{l}0.000 \\
(0.02)\end{array}$ & $\begin{array}{l}-0.001 \\
(0.07)\end{array}$ \\
\hline No. of sectors & $\begin{array}{l}0.004 \\
(0.14)\end{array}$ & $\begin{array}{l}0.039 \\
(1.34)\end{array}$ & $\begin{array}{l}-0.017 \\
(0.27)\end{array}$ & $\begin{array}{l}-0.151 \\
(3.60)^{* * *}\end{array}$ & $\begin{array}{l}-0.078 \\
(1.14)\end{array}$ & $\begin{array}{l}-0.095 \\
(2.14)^{* *}\end{array}$ & $\begin{array}{l}0.148 \\
(3.30)^{* * *}\end{array}$ & $\begin{array}{l}0.147 \\
(3.15)^{* * *}\end{array}$ & $\begin{array}{l}0.153 \\
(3.16)^{* * *}\end{array}$ \\
\hline Family & $\begin{array}{l}0.059 \\
(0.58)\end{array}$ & & $\begin{array}{l}0.325 \\
(1.43)\end{array}$ & $\begin{array}{l}0.043 \\
(0.30)\end{array}$ & & $\begin{array}{l}0.234 \\
(1.27)\end{array}$ & $\begin{array}{l}0.113 \\
(0.76)\end{array}$ & & $\begin{array}{l}0.039 \\
(0.16)\end{array}$ \\
\hline Foreign & $\begin{array}{l}-0.501 \\
(2.31)^{* *}\end{array}$ & & $\begin{array}{l}-0.671 \\
(1.38)\end{array}$ & $\begin{array}{l}-1.246 \\
(2.92)^{* * *}\end{array}$ & & $\begin{array}{l}-0.957 \\
(1.83)^{*}\end{array}$ & $\begin{array}{l}-0.141 \\
(0.54)\end{array}$ & & $\begin{array}{l}-0.831 \\
(1.55)\end{array}$ \\
\hline Crisis & & $\begin{array}{l}-0.259 \\
(2.10)^{* *}\end{array}$ & & & $\begin{array}{l}-0.592 \\
(2.08)^{* *}\end{array}$ & & & $\begin{array}{l}0.257 \\
(1.39)\end{array}$ & \\
\hline Post-crisis & & $\begin{array}{l}-0.667 \\
(4.91)^{* * *}\end{array}$ & & & $\begin{array}{l}-1.168 \\
(3.70)^{* * *}\end{array}$ & & & $\begin{array}{l}-0.091 \\
(0.46)\end{array}$ & \\
\hline Crisis*Family & & & $\begin{array}{l}-0.530 \\
(2.21)^{* *}\end{array}$ & & & $\begin{array}{l}-0.903 \\
(4.06)^{* * *}\end{array}$ & & & $\begin{array}{l}0.011 \\
(0.05)\end{array}$ \\
\hline Crisis* Foreign & & & $\begin{array}{l}0.582 \\
(0.95)\end{array}$ & & & $\begin{array}{l}-0.703 \\
(0.62)\end{array}$ & & & $\begin{array}{l}1.338 \\
(2.21)^{* *}\end{array}$ \\
\hline Crisis* DI & & & $\begin{array}{l}0.154 \\
(0.59)\end{array}$ & & & $\begin{array}{l}-0.148 \\
(0.62)\end{array}$ & & & $\begin{array}{l}0.343 \\
(1.35)\end{array}$ \\
\hline Post-crisis* Family & & & $\begin{array}{l}-0.543 \\
(2.13)^{* *}\end{array}$ & & & $\begin{array}{l}-1.046 \\
(4.32)^{* * *}\end{array}$ & & & $\begin{array}{l}0.134 \\
(0.55)\end{array}$ \\
\hline Post-crisis* Foreign & & & $\begin{array}{l}-0.041 \\
(0.06)\end{array}$ & & & $\begin{array}{l}-1.255 \\
(1.11)\end{array}$ & & & $\begin{array}{l}0.557 \\
(0.84)\end{array}$ \\
\hline Post-crisis*DI & & & $\begin{array}{l}-0.831 \\
(2.68)^{* * *}\end{array}$ & & & $\begin{array}{l}-1.290 \\
(4.12)^{* * *}\end{array}$ & & & $\begin{array}{l}-0.621 \\
(1.95)^{*}\end{array}$ \\
\hline Constant & $\begin{array}{l}2.042 \\
(2.07)^{* *}\end{array}$ & $\begin{array}{l}3.212 \\
(3.19)^{* * *}\end{array}$ & $\begin{array}{l}3.493 \\
(2.40)^{* *}\end{array}$ & $\begin{array}{l}1.790 \\
(1.29)\end{array}$ & $\begin{array}{l}3.787 \\
(1.84)^{*}\end{array}$ & $\begin{array}{l}3.471 \\
(2.41)^{* *}\end{array}$ & $\begin{array}{l}0.695 \\
(0.49)\end{array}$ & $\begin{array}{l}1.156 \\
(0.81)\end{array}$ & $\begin{array}{l}1.144 \\
(0.79)\end{array}$ \\
\hline Observations & 581 & 581 & 581 & 581 & 581 & 581 & 581 & 581 & 581 \\
\hline Pseudo $R^{2}$ & 0.20 & 0.21 & 0.13 & 0.25 & 0.27 & 0.28 & 0.17 & 0.17 & 0.18 \\
\hline
\end{tabular}

This table reports estimates of Poisson models on the number of subsidiaries divested by a firm from 1994 to 2002 . The sample consists of all firms listed on Thai Stock Exchange with at least one subsidiary at the beginning of the sample period. We further cut the time span into three periods: pre-crisis (1994 to 1996), crisis (1997 to 1999) and post-crisis (2000 to 2002). The unit of observation is a firm-period. We report estimates for the total number of subsidiaries divested (Total divestiture - columns (1) to (3)); the number of subsidiaries divested within the parent firm's core business (Core divestiture - columns (4) to (6)); and the number of subsidiaries divested within the parent firm's peripheral business (Peripheral divestiture - columns (7) to (9). Total expansion is the number of subsidiaries acquired during the same period. Firm size is the logarithm of a firm's total assets. Change in ROA denotes the difference in ROA from the beginning and the end of a period. Current ratio is calculated as current assets divided by current liabilities. No. of subs is the number of subsidiaries a firm owns at the beginning of a period. No. of sectors is the number of sectors (two-digit SIC equivalent) that a firm owns at least one subsidiary. SubHHI denotes the Herfindahl index based on a firm's ownership shares in each of its subsidiaries. We classify firms into three ownership type based on total number of shares owned by their top ten shareholders. Family firms are mostly owned by domestic individuals with block shares; DI firms are mostly owned by domestic institutions and foreign firms are mostly owned by foreign investors. DI is omitted as benchmark for comparisons. All estimations control for sector fixed effects. Heteroskedasticity robust standard errors are used in calculating Z-statistics in parentheses.

$*$ significant at $10 \%$, **significant at $5 \%$, *** significant at $1 \%$.

subsidiaries in the core segments that are divested. Because we do not have much information on subsidiaries' positions in the pyramid, we leave detailed investigation of tunneling for future study.

We define refocusing based on cross-industry divestitures, which is consistent with prior literature on refocusing. However, there are many ways to define what is a core asset and hence what is refocusing. We use alternative ways to capture the "core" assets by assessing the significance of the subsidiaries to the parent firm. We first control for subsidiary size. Our results in Table 6 show that in the parent firms' primary industry, larger subsidiaries are less likely to be divested. As a robustness check, we also redefine core subsidiaries as those in which the parent firm owns more than $50 \%$ of the shares. Results based on this redefinition are similar to those in our main regressions. Finally, firms may engage in refocusing by trimming or shedding core assets. Unfortunately, we are not able to examine this possibility due to data limitation.

Our investigation also focuses on total withdrawal of investments by a parent from its subsidiary. In reality, a parent company can also partially reduce its involvement in a subsidiary through equity carve-outs, i.e., selling part of the ownership in the 
Table 9

Poisson estimation of subsidiary divestiture and addition: group vs. non-group family firms.

\begin{tabular}{|c|c|c|c|c|c|c|}
\hline & \multicolumn{3}{|c|}{ Total divestiture } & \multicolumn{3}{|c|}{ Total expansion } \\
\hline & (1) & $(2)$ & $(3)$ & (4) & $(5)$ & $(6)$ \\
\hline Business Group (BG) & $\begin{array}{l}0.297 \\
(1.36)\end{array}$ & & $\begin{array}{l}1.049 \\
(4.63)^{\text {*** }}\end{array}$ & $\begin{array}{l}0.398 \\
(1.93)^{*}\end{array}$ & & $\begin{array}{l}0.773 \\
(5.59)^{* * *}\end{array}$ \\
\hline FirmSIZE & $\begin{array}{l}0.144 \\
(1.13)\end{array}$ & $\begin{array}{l}0.123 \\
(1.07)\end{array}$ & $\begin{array}{l}0.049 \\
(0.65)\end{array}$ & $\begin{array}{l}0.430 \\
(3.62)^{* * *}\end{array}$ & $\begin{array}{l}0.389 \\
(3.12)^{* * *}\end{array}$ & $\begin{array}{l}0.305 \\
(5.75)^{* * *}\end{array}$ \\
\hline Change in ROA & $\begin{array}{l}-1.991 \\
(1.67)^{*}\end{array}$ & $\begin{array}{l}-1.566 \\
(1.40)\end{array}$ & $\begin{array}{l}-1.295 \\
(2.02)^{* *}\end{array}$ & $\begin{array}{l}-1.811 \\
(1.56)\end{array}$ & $\begin{array}{l}-0.375 \\
(0.42)\end{array}$ & $\begin{array}{l}-0.687 \\
(1.10)\end{array}$ \\
\hline Current ratio & $\begin{array}{l}-0.088 \\
(1.55)\end{array}$ & $\begin{array}{l}-0.092 \\
(1.32)\end{array}$ & $\begin{array}{l}-0.056 \\
(1.24)\end{array}$ & $\begin{array}{l}-0.030 \\
(0.55)\end{array}$ & $\begin{array}{l}-0.017 \\
(0.34)\end{array}$ & $\begin{array}{l}-0.003 \\
(0.10)\end{array}$ \\
\hline SubHHI & $\begin{array}{l}-1.195 \\
(2.50)^{* *}\end{array}$ & $\begin{array}{l}-1.264 \\
(2.98)^{* * *}\end{array}$ & $\begin{array}{l}-1.327 \\
(4.54)^{\text {*** }}\end{array}$ & $\begin{array}{l}-0.300 \\
(0.64)\end{array}$ & $\begin{array}{l}-0.497 \\
(1.32)\end{array}$ & $\begin{array}{l}-0.445 \\
(2.33)^{* *}\end{array}$ \\
\hline No. of subs & $\begin{array}{l}0.068 \\
(3.35)^{* * *}\end{array}$ & $\begin{array}{l}0.070 \\
(4.06)^{* * *}\end{array}$ & $\begin{array}{l}0.052 \\
(4.27)^{\text {*** }}\end{array}$ & $\begin{array}{l}0.061 \\
(2.55)^{* *}\end{array}$ & $\begin{array}{l}0.049 \\
(2.87)^{\text {*** }}\end{array}$ & $\begin{array}{l}0.033 \\
(3.80)^{* * *}\end{array}$ \\
\hline No. of sectors & $\begin{array}{l}-0.187 \\
(2.28)^{* *}\end{array}$ & $\begin{array}{l}-0.122 \\
(1.56)\end{array}$ & $\begin{array}{l}-0.050 \\
(0.95)\end{array}$ & $\begin{array}{l}-0.345 \\
(4.85)^{* * *}\end{array}$ & $\begin{array}{l}-0.132 \\
(1.83)^{*}\end{array}$ & $\begin{array}{l}-0.128 \\
(2.92)^{* * *}\end{array}$ \\
\hline Crisis & & $\begin{array}{l}-0.485 \\
(2.20)^{* *}\end{array}$ & $\begin{array}{l}0.193 \\
(0.83)\end{array}$ & & $\begin{array}{l}-1.425 \\
(5.60)^{* * *}\end{array}$ & $\begin{array}{l}-1.678 \\
(7.14)^{* * *}\end{array}$ \\
\hline Post-crisis & & $\begin{array}{l}-0.467 \\
(1.99)^{* *}\end{array}$ & $\begin{array}{l}-0.193 \\
(0.69)\end{array}$ & & $\begin{array}{l}-1.047 \\
(4.81)^{* * *}\end{array}$ & $\begin{array}{l}-1.007 \\
(4.69)^{* * *}\end{array}$ \\
\hline Crisis*BG & & & $\begin{array}{l}-1.494 \\
(4.82)^{* * *}\end{array}$ & & & $\begin{array}{l}0.201 \\
(0.72)\end{array}$ \\
\hline Post-crisis* BG & & & $\begin{array}{l}-0.825 \\
(2.47)^{* *}\end{array}$ & & & $\begin{array}{l}-0.257 \\
(1.01)\end{array}$ \\
\hline Constant & $\begin{array}{l}-1.891 \\
(0.96)\end{array}$ & $\begin{array}{l}-1.411 \\
(0.79)\end{array}$ & $\begin{array}{l}-0.664 \\
(0.60)\end{array}$ & $\begin{array}{l}-5.459 \\
(2.99)^{* * *}\end{array}$ & $\begin{array}{l}-4.454 \\
(2.43)^{* *}\end{array}$ & $\begin{array}{l}-3.341 \\
(4.23)^{* * *}\end{array}$ \\
\hline Observations & 275 & 275 & 275 & 275 & 275 & 275 \\
\hline Pseudo $R^{2}$ & 0.26 & 0.26 & 0.30 & 0.27 & 0.35 & 0.37 \\
\hline
\end{tabular}

This table reports estimates of Poisson models on the number of subsidiaries divested and acquired by a firm from 1994 to 2002 . The sample consists of all firms which are mostly owned by Thai individuals (Family firms). We classify firms into two categories. Business Group (BG) is a firm that is affiliated with one of the 150 leading Thai business groups identified in (Brooker Group and TARA (1997). We further cut the time span into three periods: pre-crisis (1994 to 1996), crisis (1997 to 1999) and post-crisis (2000 to 2002). The unit of observation is a firm-period. We report estimates for the total number of subsidiaries divested (Divestiture columns (1) to (3)) and the number of subsidiaries acquired (Expansion - columns (4) to (6)). Firm size is the logarithm of a firm's total assets. Change in ROA denotes the difference in ROA from the beginning and the end of a period. Current ratio is calculated as current assets divided by current liabilities. No. of subs is the number of subsidiaries a firm owns at the beginning of a period. No. of sectors is the number of sectors (two-digit SIC equivalent) that a firm owns at least one subsidiary. SubHHI denotes the Herfindahl index based on a firm's ownership shares in each of its subsidiaries. DI is omitted as benchmark for comparisons. All estimations control for sector fixed effects. Heteroskedasticity robust standard errors are used in calculating Z-statistics in parentheses.

* significant at $10 \%, * *$ significant at $5 \%$, *** significant at $1 \%$.

subsidiary to a third party. Rather than its subsidiaries, a parent also can restructure its own assets. To capture restructuring of the parent's own assets we would need data on asset sale by the parent in its core and peripheral segments, respectively. Due to data limitation, partial divestment, as well as divestment of assets from the parent's own balance sheet, is left for future study.

In conclusion, our study highlights the different costs of financial distress for domestic and multinational firms and the unique competitive advantages resulting from the differential impact of financial crisis in countries with weak financial markets such as Thailand. It also provides new evidence on the importance of operational focus, financial constraints and ownership structure to firms' decision about corporate restructuring.

\section{Acknowledgements}

We thank the seminar participants at Georgetown University and University of Maryland, and the participants at the 2009 Journal of Corporate Finance Conference on Corporate Finance and Governance in Emerging Markets in Beijing for useful comments. We are especially grateful to an anonymous referee for insightful comments. Fritz Foley kindly provided part of the data. Maggie Zhou wishes to thank the Mitsui Life Doctoral Research Fellowship on Emerging Markets at the University of Michigan and Jan Svejnar the Grant Agency of the Czech Republic (Grant No. P402/10/2130) for financial support. Jan Svejnar also benefitted from a stay at CERGE-EI, a joint workplace of Charles University and the Academy of Sciences of the Czech Republic, while writing this paper. All errors are our own.

\section{References}

Acharya, Viral V., Shin, Hyun Song, Yorulmazer, Tanju, 2007a. Fire-sale FDI. SSRN Working Paper.

Acharya, Viral V., Shin, Hyun Song, Yorulmazer, Tanju, 2007b. Fire sales, foreign entry and bank liquidity. SSRN Working Paper.

Aguiar, Mark, Gopinath, Gita, 2005. Fire-sale foreign direct investment and liquidity crises. Rev. Econ. Stat. 87, 439-452.

Anderson, Ronald C., Reeb, David M., 2003a. Founding-family ownership and firm performance: evidence from the S\&P 500. J. Finance 58, $1301-1328$.

Anderson, Ronald C., Reeb, David M., 2003b. Founding-family ownership, corporate diversification, and firm leverage. J Law Econ. XLVI, $653-684$. 
Andrade, Gregor, Kaplan, Steven N., 1998. How costly is financial (not economic) distress? Evidence from highly leveraged transactions that became distressed. J. Finance 53, 1443-1493.

Baek, Jae-Seung, Kang, Jun-Koo, Park, Kyung Suh, 2004. Corporate governance and firm value: evidence from the Korean financial crisis. J Financ. Econ. 71, 265-313.

Berger, Philip G., Ofek, Eli, 1995. Diversification's effect on firm value. J. Financ. Econ. 37, 39-65.

Berger, Philip G., Ofek, Eli, 1999. Causes and effects of corporate refocusing programs. Rev. Financ. Stud. 12, 311-345.

Bertrand, Marianne, Johnson, Simon, Samphantharak, Krislert, Schoar, Antoinette, 2008. Mixing family with business: a study of Thai business groups and the families behind them. J. Financ. Econ. 88, 466-498.

Brooker Group, and TARA, 1997. Thai Business Groups 1996/1997 (TARA Siam Business Information Limited, Bangkok, Thailand).

Burch, Timothy R., Nanda, Vikram, 2003. Divisional diversity and the conglomerate discount: evidence from spinoffs. J. Financ. Econ. 70, 69-98.

Claessens, Stijn, Djankov, Simeon, Fan, Joseph P.H., Lang, Larry H.P., 2002. Disentangling the incentive and entrenchment effects of large shareholdings. J. Finance $57,2741-2772$.

Claessens, Stijn, Djankov, Simeon, Lang, Larry H.P., 2000. The separation of ownership and control in East Asian Corporations. J Financ. Econ. 58, 81-112.

Comment, Robert, Jarrell, Gregg A., 1995. Corporate focus and stock returns. J. Financ. Econ. 37, 67-87.

Daley, Lane, Mehrotra, Vikas, Sivakumar, Ranjini, 1997. Corporate focus and value creation evidence from spinoffs. J. Financ. Econo. 45, 257-281.

Desai, Hemang, Jain, Prem C., 1999. Firm performance and focus: long-run stock market performance following spinoffs. J. Financ. Econ. 54, 75-101.

Diamond, Douglas W., Rajan, Raghuram G., 2009. Fear of fire sales and the credit freeze. NBER Working Paper.

Dittmar, Amy, Shivdasani, Anil, 2003. Divestitures and divisional investment policies. J. Finance 58, 2711-2743.

Easterbrook, Frank H., 1990. Is corporate bankruptcy efficient? J. Financ. Econ. 27, 411-417.

Foley, C. Fritz, 2001. Going Bust in Bangkok: Lessons from Bankruptcy Reform in Thailand. Harvard University, Working Paper

Foley, C. Fritz, Desai, Mihir A., Forbes, Kristin J., 2008. Financial constraints and growth: multinational and local firm responses to currency depreciations. Rev. Financ. Stud. 21, 2857-2888.

Hewison, Kevin, 1989. Bankers and Bureaucrats: Capital and the Role of the State in Thailand. Yale University Southeast Asia Studies, New Haven.

Hewison, Kevin, 2003. The politics of neo-liberalism: class and capitalism in contemporary Thailand. Working Paper, Southeast Asia Research Center, City University of Hong Kong.

Holderness, Clifford G., Sheehan, Dennis P., 1988. The role of majority shareholders in publicly held corporations: an exploratory analysis. J. Financ. Econ. 20, 317-346.

Jensen, Michael C., Meckling, William H., 1976. Theory of the firm: managerial behavior, agency costs and ownership structure. J. Financ. Econo. 3, 305-360.

John, Kose, Lang, Larry H.P., Netter, Jeffry, 1992. The voluntary restructuring of large firms in response to performance decline. J. Finance 47, 891-917.

John, Kose, Ofek, Eli, 1995. Asset sales and increase in focus. J. Financ. Econ. 37, 105-126.

Johnson, Richard A., 1996. Antecedents and outcomes of corporate refocusing. J. Manage. 22, 439-483.

Johnson, Richard A., Hoskisson, Robert E., Hitt, Michael A., 1993. Board of director involvement in restructuring: the effects of board versus managerial controls and characteristics. Strategic Manage. J. 14, 33-50.

Johnson, Simon, López-de-Silanes, F., Shleifer, A., Vishny, R., 2000. Tunneling. Am. Econ. Rev. Pap. Proc. 90, 22-27.

Krishnaswami, Sudha, Subramaniam, Venkat, 1999. Information asymmetry, valuation, and the corporate spin-off decision. J. Financ. Econ. $53,73$.

Krugman, Paul, 1998, Fire Sale FDI, (http://web.mit.edu/krugman/www/FIRESALE.htm).

La Porta, Rafael, Lopez-de-Silanes, Florencio, Shleifer, Andrei, 1999. Corporate ownership around the world. J. Finance 54, 471-517.

Lang, Larry, Poulsen, Annette, Stulz, Rene, 1995. Asset sales, firm performance, and the agency costs of managerial discretion. J. Financ. Econ. 37, 3.

Lemmon, Michael L., Lins, Karl V., 2003. Ownership structure, corporate governance, and firm value: evidence from the East Asian Financial Crisis. J. Finance 58, $1445-1468$.

Morck, Randall, Wolfenzon, Daniel, Yeung, Bernard, 2004. Corporate governance, economic entrenchment and growth. J. Econ. Lit. 43, 655-720.

Pasuk, Phongpaichit, Baker, Chris, 2002. Thailand: Economy and Politics. Oxford University Press, Kuala Lumpur.

Shleifer, A., Vishny, R.W., 1997. A survey of corporate governance. J. Finance 52, 737-783.

Shleifer, Andrei, Vishny, Robert W., 1986. Large shareholders and corporate control. J. Political Economy 94, 461-488.

Shleifer, Andrei, Vishny, Robert W., 1992. Liquidation values and debt capacity: a market equilibrium approach. J. Finance 47, 1343-1366.

Sidel, Robin, Dennis K. Berman, and Kate Kelly, 2008, J.P. Morgan buys bear in fire sale, as fed widens credit to avert crisis: ailing firm sold for just \$2 a share in U.S.-backed deal, The Wall Street Journal.

Stiglitz, Joseph, 2000, What I learned at the World Economic Crisis, The New Republic.

UNCTAD, 1999. Report on Trends in FDI. United Nations Conference on Trade and Development, Commission on Investment, Technology and RElated Financial Issues (Geneva).

Villalonga, Belen, Amit, Raphael, 2006. How do family ownership, control and management affect firm value? J. Financ. Econ. 80, 385-417.

Vongvipanond, Pairoj, Wichitaksorn, Nuttanan, 2004. Thailand's corporate restructuring experience through formal bankruptcy procedures: economic and legal perspectives. ASEAN Econ. Bull. 21, 54.

World Bank, 1993. The East Asian Miracle: Economic Growth and Public Policy. Oxford University Press, New York. 